ISSN: 0213-2060

DOI: http://dx.doi.org/10.14201/shhme201634243269

\title{
LA ÇIBDAD ESTÁ ESCANDALIZADA. PROTESTAS SOCIALES Y LUCHA DE FACCIONES EN LA TOLEDO BAJOMEDIEVAL
}

\author{
La çibdad está escandalizada. Social Unrest and Factional Fight in Late \\ Medieval Toledo
}

Óscar LÓPEZ GÓMEZ
Depto. de Historia Medieval. Facultad de Geografía e Historia. Universidad Complutense de Madrid. C/ Profesor
Aranguren, s/n. E-28040 MADRID. C. e.: osclop01@ucm.es

Recibido: 2015-04-08

Revisado: 2015-09-04

Aceptado: 2016-10-14

RESUMEN: Aunque las revueltas acaecidas desde el siglo XIII sirvieron sobre todo para instruir a las organizaciones estatales del Occidente europeo en la defensa del status quo sociopolítico, nunca se logró acallar la voz del común. Lo evidencian así los centenares de testimonios conservados hasta nuestros días, en que pueden leerse actos de protesta de toda especie: desde los nacidos en la intimidad del odio frente al noble hasta los que surgían de manera desesperada, fruto del colapso de situaciones que se creían insostenibles. Protestas individuales, de colectivos religiosos o artesanos, en masa; mediante el uso de cánticos y $p a-$ labras escandalosas, de manera pacífica o con una violencia feroz. Era en los prolegómenos de las grandes sublevaciones cuando el discurso reivindicativo se volvía más cruento, dotando de una base ideológica a la consecución de fines a los que aspiraban tanto grupos sociales en conjunto como individuos poderosos específicos.

Palabras clave: Revuelta; Discurso subversivo; Bandos políticos; Violencia; Movimientos sociales.

ABSTRACT: Although the riots occurred since the thirteenth Century served mainly to educate the state organizations in Western Europe in the defense of the sociopolitical 
ÓSCAR LÓPEZ GÓMEZ

LA CIIBDAD ESTÁ ESCANDALIZADA. PROTESTAS SOCIALES Y LUCHA DE FACCIONES

EN LA TOLEDO BAJOMEDIEVAL

status quo, the voice of the comun never was silenced. The evidence and hundreds of testimonials preserved until today show us protests of all kinds: from those born in the privacy of hate against the noble to those who desperately emerged, result of the collapse of situations that are believed untenable. Individual protests, religious groups and artisans, in masse; using songs and scandalous words, peacefully or with ferocious violence. It was on the eve of the uprisings when the protest turned bloodiest speech, providing an ideological basis for the achievement of purposes for both aspiring social groups together as specific powerful individuals.

Keywords: Revolt; Subversive discourse; Political factions; Violence; Social movements.

SUMARIO: 0 Introducción. 1 La definición de la protesta según los textos toledanos del siglo xv. 1.1 Ámbitos de las críticas: las categorías de la organización social y sus estructuras artificiales. 1.2. Métodos y espacios de acusación. 1.3 Las fiestas: tiempos de diversión y crítica. 2 La protesta y el papel de las facciones políticas. 2.1 Antes de los alborotos: los discursos de permanencia, modificación y cambio. 2.2 Las ceremonias del escándalo. 2.3 ...oyeron la grita de la gente, cómo ya se levantaba la dicha ciudad... 3 A modo de conclusión. 4. Referencias bibliográficas.

\section{$0 \quad$ INTRODUCCIÓN $^{1 *}$}

Lejos de tratarse de un tema agotado historiográficamente -como se llegó a pensar en la década de 1990, dada la crisis del materialismo histórico ${ }^{2}$-, el estudio de los movimientos sociales acaecidos en el Antiguo Régimen disfruta hoy de un vigor renovado e ilusionante ${ }^{3}$, fruto de la influencia de disciplinas hermanas de la Historia como la Antropología, la Psicología y la Politología, pero también gracias a la labor de no pocos historiadores ávidos de escritos susceptibles de ser analizados a la luz de planteamientos diferentes. A menudo en las líneas de la nueva historia cultural, si bien lejos de etiquetas

1 * Siglas utilizadas: ACT= Archivo de la Catedral de Toledo; AGS= Archivo General de Simancas; AHME = Archivo Histórico Municipal de Escalona; AMT = Archivo Municipal de Toledo; ACJ= Archivo del Cabildo de Jurados; ARChV= Archivo de la Real Chancillería de Valladolid; AS= Archivo Secreto; CC= Cámara de Castilla; $\mathrm{DO}=$ Documentos originales; $\mathrm{RH}=$ Real Academia de la Historia; RGS= Registro General del Sello.

2 El presente trabajo se ha realizado en el marco del proyecto: «La jerarquización urbana: villas y ciudades en Castilla (1400-1561)», del MICINN, HAR2013-44014-P. Un avance se expuso en la XXVII Asamblea General de la SEEM. Congreso Internacional Formas de protesta, movilización y lucha politica en la Baja Edad Media: lenguajes, discursos e imaginarios sociales. 17 al 19 de septiembre de 2014. Universidad de Valladolid. Facultad de Filosofía y Letras, en una comunicación titulada «Cuando las palabras ya no sirven: el colapso de las protestas sociales y la acción colectiva en la Toledo bajomedieval».

3 La cuestión de la crisis del materialismo histórico ha hecho correr ríos de tinta. Véase, por ejemplo: Blackledge, Paul. Reflections on the Marxist Theory of History. Manchester: University Press, 2006; Kaye, Harvey J. La educación del deseo: los marxistas y la escritura de la Historia. Madrid: Talasa, 2007; González Soriano, José Antonio. Racionalidad revolucionaria: apunte de epistemología para el materialismo histórico. Madrid: Biblioteca Nueva, 2008. 
historiográficas y de encorsetamientos metodológicos ${ }^{4}$, en la actualidad se insiste en los múltiples ángulos desde los que pueden enfocarse los conflictos: tanto en lo concerniente a su gestación y sus repercusiones como en la multiplicidad de aspectos dignos de ser evaluados en su desarrollo: patrones de movilización social, rol de las élites, facciones y microfacciones ${ }^{5}$, grupos laborales insumisos ${ }^{6}$, estrategias de lucha, actividad propagandística y discursos (des)legitimadores, la cultura política que animaba a la insurrección 7 , el armamento, la coreografía de las masas en las revueltas ${ }^{8}$, los líderes reconocidos y los mártires populares, las pacificaciones ficticias y las treguas artificiosas, la imbricación entre delincuencia común y violencia colectiva, o el papel de las mujeres y los jóvenes?

En los últimos años se ha puesto especial atención en el simbolismo y los rituales que se explicitaban en los alborotos y, relacionado con ello, en los discursos, el lenguaje, los rumores ${ }^{10}$, los eslóganes, los gritos de desobediencia, las proclamas, los pregones ${ }^{11}$, las voces o apellidos -que servían para reclamar el socorro de la clientela-, los poemas y, en fin, los cánticos que enriquecían las confrontaciones, que las dotaban de cuerpo ideológi$\mathrm{Co}^{12}$. En este sentido, el futuro del análisis de las revueltas pasaría, según ciertos autores, por una valoración minuciosa del lenguaje existente en las sociedades del pasado ${ }^{13}$. Dos de los medievalistas que lo han defendido así, Jan Dumolyn y Jelle Haemers, señalaban en un trabajo que vio la luz no hace mucho que las protestas, los rumores, las burlas y, en general, los discursos contra el poder habría que incardinarlos en un entorno de prácticas establecido por la tradición, en el que eran significativas las emociones y la violencia

4 VÁzquez Gestal, Pablo. «Despegándose del texto. Los juegos de la "Nueva Historia Cultural": Descripción, narración e interpretación». Memoria y Civilización, 2001, vol. 4, pp. 151-186.

5 SATo, Hitomi. «Fazioni e microfazioni: guelfi e ghibellini nella montagna bergamasca del Trecento». Bergomum. Bollettino Annuale della Civica Biblioteca Angelo Mai di Bergamo, 2009-2010, vol. 104-105, pp. 149-170.

6 Los odreros en la Toledo del siglo xv, o los carniceros en la Siena del xiv: Costantini, Valentina. «Siena, 1318: la congiura di "carnaioli", notai e magnati contro il governo dei Nove». Studi Storici, 2011, vol. 52/1, pp. 229-252; "On the red line across Europe: Butchers and Rebellions in fourteenth-century Siena». Social History, 2016, vol. 41/1, pp. 72-92; «Tra lavoro e rivolta: i carnaioli senesi nello specchio del Costituto del 1309-10». En Giordano, Nora y Piccinni, Gabriella (a cura di). Siena nello specchio del suo Costituto in volgare del 1309-1310. Siena: Pacini Editore, 2014, pp. 219-247.

7 Alan Sizer, Michael. Making Revolution Medieval: Revolt and Political Culture in Late Medieval Paris. Minessota: University of Minessota, 2008; Monsalvo Antón, José María. «Ideario sociopolítico y valores estamentales de los pecheros abulenses y salmantinos (ss. XIII-Xv)». Hispania. Revista Española de Historia, 2011, vol. 71, n. ${ }^{\circ}$ 238, pp. 325-362.

8 Dumolyn, Jan y Haemers, Jelle. «A Bad Chicken Was Brooding: Subversive Speech in Late Medieval Flanders». Past and Present, 2012, vol. 214, pp. 45-86. En concreto p. 46.

9 Bodden, M. C. Language as the Site of Revolt in Medieval and Early Modern England: Speaking as a Woman. London: Palgrave Macmillan, 2011.

10 Carrasco Manchado, Ana Isabel. «El rumor político. Apuntes sobre la opinión pública en la Castilla del siglo XV». Cuadernos de Historia de España, 2006, vol. 80, pp. 65-90.

11 Nieto Soria, José Manuel. «El pregón en la vida política de la Castilla trastámara». Edad Media. Revista de Historia, 2012, vol. 13, pp. 77-102.

12 Dumolyn, Jan. "Cries and Shouters. The Discourse on Radical Urban Rebels in Late Medieval Flanders». Journal of Social History, 2008, vol. 42/1, pp. 111-135.

13 Dumolyn, Jan. «Political Communication and Political Power in the Middle Ages: a Conceptual Journey». Edad Media. Revista de Historia, 2012, 13, pp. 33-55. 
ÓSCAR LÓPEZ GÓMEZ

de carácter simbólico. Según este planteamiento, el «lenguaje subversivo sería uno de los factores omnipresentes en la vida política» de las urbes, "porque creó un escenario permanente de posicionamiento para sus sujetos». Existiera o no violencia física, el pensamiento subversivo y lo que conllevaba eran «la regla en la cotidianidad de los centros urbanos de la tardía Edad Media» ${ }^{14}$. Según Dumolyn y Haemers, Gante sería un ejemplo paradigmático, tanto por la actividad sediciosa que vivió a fines del Medievo e inicios de la Edad Moderna como por las repercusiones que ha dejado el castigo de los disturbios, visible aún en algunas fiestas populares ${ }^{15}$.

En efecto, el 90\% de las revueltas de la Baja Edad Media descritas por los cronistas tuvieron lugar en un núcleo urbano ${ }^{16}$. Más allá de alzamientos como el de los remensas en Cataluña o los irmandiños en Galicia ${ }^{17}$, los movimientos sociales acontecidos en Francia, Italia, Flandes o los reinos de la Península Ibérica vienen a poner de manifiesto que el individuo más susceptible de rebelarse a fines del Medievo era el ciudadano; no el campesino. Se trata de otra secuela del desarrollo del estado moderno. Para los líderes de las formaciones estatales - reyes, nobles, clérigos- el peligro habitaba en las urbes. Si bien, lejos de servir las generalizaciones, cada ciudad tenía su idiosincrasia, y en Europa convivían núcleos urbanos en términos generales pacíficos, como Ávila o Venecia, junto a otros con una terrible fama de alborotos y rebeliones, como Ypres, Gante, Florencia o Toledo.

Era frecuente que en las comunidades escandalosas pesaran tanto cuestiones políticas, socioeconómicas y de carácter religioso como su propio pasado levantisco. Existía en ellas una memoria social ${ }^{18}$, una consciencia del poder del pueblo, que espoleaba a la insubordinación entre los escalafones sociales más bajos y en la oligarquía. En Toledo, en el núcleo urbano sobre el que se tratará en las páginas que siguen, la memoria colectiva se asentaba en una tradición de historias, mitos y leyendas que circulaban entre

14 Dumolyn y Haemers, "A Bad Chicken», pp. 55-56 y 86

15 La represión más sonada es la que se produjo en el año 1537 tras la negativa de la población de financiar las guerras de Carlos V contra el rey de Francia. El propio emperador se hizo cargo del motín marchando sobre la urbe con 5.000 soldados, con quienes impuso sus deseos y llevó a cabo un castigo implacable: la ciudad perdió sus derechos y fue degradada al rango de ciudad de segunda; la campana Roeldan, símbolo de la independencia gantesa, fue descolgada de la torre municipal; las puertas de la muralla fueron derribadas; y gran parte de los ciudadanos fueron ahorcados o tuvieron que rendirse ante el emperador públicamente, en una ceremonia de la vergüenza que tuvo lugar tras diez días en que ciudadanos de todo tipo, desde menestrales a nobles, fueron acusados de desobediencia, falsificación de documentos, insurrección popular, rebeldía y delito de lesa majestad. En medio de la desesperación por el ahorcamiento multitudinario, los más afortunados, sobre quienes la represión no fue tan feroz, dirigidos por un cortejo de ilustres de la ciudad hubieron de doblegarse a su señor y pedir clemencia en voz alta, saliendo por las calles descalzos, con una simple camisa, y andando sujetos por una cuerda alrededor del cuello. En recuerdo los ganteses han guardado el apodo «stroppendragers»: los que llevan un lazo alrededor del cuello. Cada año hay un desfile del gremio de los stroppendragers en las fiestas de Gante que recuerda el hecho. De igual modo, el día de Castilla y León es el 23 de abril; jornada que hace referencia a lo ocurrido en Villalar ese día de 1521, cuando los comuneros fueron derrotados.

16 Cohn, Samuel K. (Jr.). Lust for Liberty. The politics of Social Revolt in Medieval Europe, 1200-1423. Italy, France and Flanders. Cambridge, Massachusetts and London: Harvard University Press, 2008.

17 Barros, Carlos. Mentalidad justiciera de los irmandiños, siglo XV. Madrid: Siglo XXI, 1990.

18 Haemers, Jelle. «Social Memory and Rebellion in Fifteenth-Century Ghent». Social History, 2011, vol. XXXVI, pp. 443-463. 
ÓSCAR LÓPEZ GÓMEZ

la opinión pública poniendo énfasis en dos cuestiones: en el papel histórico preponderante de la ciudad -urbs regia del Reino Visigodo, plaza influyente en época andalusí, metrópoli con un carácter legitimador básico para la monarquía-; y en el poderío de su pueblo cuando se alzaba, al parecer irrefrenable, como incluso reconocerían los cronistas de los reyes ${ }^{19}$. En virtud del imaginario forjado en torno a sus leyendas y su historia ${ }^{20}$, la comunidad de Toledo se labró una fama que le permitiría sortear los castigos de la corona, dirigirse al reino la primera en las reuniones de $\operatorname{cortes}^{21}$, y, llegado el caso, alzarse con una confianza rotunda.

\section{LA DEFINICIÓN DE LA PROTESTA SEGÚN LOS TEXTOS TOLEDANOS DEL SIGLO XV}

Puesto que las fuentes narrativas y judiciales hablan poco de las esperanzas, aspiraciones y planes de la mayoría de las personas, hay que ir con cuidado para no leer en los documentos más de lo que contienen ${ }^{22}$. La sociedad medieval era iletrada, y las opiniones o no se ponían por escrito o, de hacerlo, se copiaban en pocos papeles ${ }^{23}$. Aquí, no obstante, también hay diferencias en los datos conservados. En el sur de Francia, por ejemplo, las voces discordantes se escuchan con más claridad en la documentación de Montpellier que en la de Lyon, Sisteron, Saint-Flour o Albi, donde se encubren las pugnas en el seno de la comunidad ${ }^{24}$. Y lo mismo sucede en Castilla; tanto en ciudades como en poblaciones secundarias. Sin ir más lejos, mientras que en Escalona los datos son abundantes y se pueden leer entre líneas opiniones en contra del gobierno ${ }^{25}$, en Talavera de la Reina, señorío de la catedral toledana, existía un control riguroso sobre las informaciones ${ }^{26}$.

19 En el caso de Fernando del Pulgar (aprox. 1436-1493) de manera amarga, pues llegó a escribir que, si Toledo era tan arrogante, se debía a los propios soberanos, que, sucumbiendo ante su pasado, no se habían atrevido a purgar los desmanes de la población como merecía, lo que la había ensoberbecido: Pulgar, Fernando del. Crónica de los Señores Reyes Católicos don Fernando y doña Isabel de Castilla y Aragón. En Crónicas de los Reyes de Castilla. Madrid: BAE, 1953, vols. LXVIII y LXX. En concreto vol. LXX, cap. 98, pp. 340-351.

20 Martínez Gil, Fernando. La invención de Toledo: imágenes históricas de una identidad urbana. Ciudad Real: Almud, 2007.

21 En pugna con Burgos: Benito Ruano, Eloy. La prelación ciudadana. Las disputas entre las ciudades de la Corona de Castilla. Toledo: Centro Universitario de Toledo, 1972.

22 Mollat, Michel y Wolff, Philippe. Uñas azules, Jacques y ciompi. Las revoluciones populares en Europa en los siglos XIV y XV. Madrid: Siglo XXI, 1989, pp. 10-11.

23 Para conocer la opinión de los menores son cruciales sus testimonios en pesquisas y juicios. Sin ir más lejos, la imagen idílica que la historiografía ha presentado del primer corregidor de Toledo en época de los Reyes Católicos, Gómez Manrique, oscurece al escuchar los testimonios de los campesinos hablando de sus abusos y encarcelamientos ilegales: AMT, AS, caj. 7. ${ }^{\circ}$, leg. $2 .^{\circ}$, n. ${ }^{\circ} 11$, fols. 9r-10r.

24 Challet, Vincent. "Nemine discrepante? Discordias y comunicación política en el seno del consulado montpellerino a fines de la Edad Media». Edad Media. Revista de Historia, 2012, vol. 13, pp. 143-161.

25 AHME, Documentación municipal, Gobierno, Actas municipales, libro 1. ${ }^{\circ}$, fol. 397r-v. Véase: López Gómez, Óscar y Ávila Seonne, Nicolás. Escalona, 1083-1554. De la repoblación a los tiempos del Lazarillo. Toledo: Diputación Provincial, 2011; López Gómez, Óscar. Álvaro de Luna y Escalona. Poder, propaganda y memoria histórica en el otoño de la Edad Media. Toledo: Diputación Provincial, 2013.

26 SuÁrez Álvarez, María Jesús. El concejo de Talavera de la Reina durante la Baja Edad Media (13691504). Oviedo: Universidad de Oviedo, 1978; y La villa de Talavera y su tierra en la Edad Media (1369-1504). Oviedo: Universidad de Oviedo, 1982; Rodríguez-Picavea Matilla, Enrique. La villa y la Tierra de Talavera 
ÓSCAR LÓPEZ GÓMEZ

LA CIIBDAD ESTÁ ESCANDALIZADA. PROTESTAS SOCIALES Y LUCHA DE FACCIONES

EN LA TOLEDO BAJOMEDIEVAL

Uno de los asuntos más difíciles de percibir en la documentación es el relativo a la protesta individual, personal, íntima. Por una parte, no siempre es factible apreciar qué se esconde tras determinado tipo de conducta, cuyos objetivos son oscuros ${ }^{27}$. Por otra, la rutina ha borrado la memoria de actos que pretendían oponerse a las más variadas cuestiones. Las autoridades estaban familiarizadas con las críticas y no les prestaban excesiva atención ${ }^{28}$. En mesones, tabernas, plazas, parroquias y conventos se oían burlas, canciones facciosas y sermones escandalosos, pero casi no han dejado rastro. Sabemos, aun así, que los reproches se basaban en estereotipos ${ }^{29}$. Defendían que los conversos querían destruir la fe verdadera; que los judíos ambicionaban el dinero; que los monjes vivían amançebados; o que los poderosos no tenían corazón ${ }^{30}$. Se trataba de argumentos repetitivos, invariables, monótonos y generalizados, evidencia de una cierta cultura de la deliberación, y del rechazo hacia el dirigente.

\section{1 Ámbitos de las criticas: las categorias de la organización social y sus estructuras artificiales}

En las urbes chocaban los fines de la caballería y de los pecheros, los de los cristianos viejos y de los conversos, y los de la oligarquía estructurada en linajes y de los individuos del común que querían participar en el gobierno; a lo que debería añadirse la conflictividad interna de la élite y de las clases populares, y la producida en el ámbito inter e intrafamiliar, en relación con herencias, espacios, cargos u oficios ${ }^{31}$. La comunidad estaba establecida sobre cinco niveles básicos de organización -la familia, la parroquia o el

en la Plena Edad Media: orígenes, consolidación y crecimiento de un concejo de realengo (siglos XI-XIII). Talavera de la Reina: Ayuntamiento de Talavera de la Reina, 1996.

27 El 9 de julio de 1502 fue ahorcado un joven en Toledo por ladrón. El castigo fue riguroso, porque los reyes y buen número de potentados estaban en la ciudad para la celebración de las Cortes que iban a reconocer a Juana como heredera del trono. No obstante, la respuesta al castigo fue rápida. Una vez el cadáver del joven quedó colgando en la horca, muchas personas se acercaron a llevarle cruces de madera y a besar sus pies en un acto de desafío manifiesto: López Gómez, Óscar. Violencia urbana y paz regia: el fin de la época medieval en Toledo (1465-1522). Tesis doctoral leída en la Facultad de Humanidades de Toledo, 2006. En RUIdeRA [Repositorio Universitario Institucional de Recursos Abiertos. Universidad de Castilla-La Mancha]: http:// hdl.handle.net/10578/2771, cap. 6, pp. 1248-1249.

28 En especial los corregidores y sus alcaldes y alguaciles, que recibirían criticas durísimas sin que eso les impidiese seguir actuando, y sin que la corona se preocupase, pues les confirmaba en su oficio año tras año. Un ejemplo sería el alcalde Gaspar Calderón, criticado y acusado por decenas de abusos: AGS, CC, Personas, leg. 5, fol. 172.

29 Gauvard, Claude. «Rumeur et stereotypes à la fin du Moyen Âge». En La circulation des nouvelles au Moyen Âge. XXIVe Congrés de la SHMES (Avignon, juin 1993). Paris: La Sorbonne-École Française de Rome-Palais Farnèse, 1994, pp. 157-177.

30 Estas argumentaciones se pueden leer en el documento más relevante generado por los toledanos en la revuelta de 1449: Benito Ruano, Eloy. «El memorial contra los conversos del bachiller Marcos García de Mora». Sefarad. Revista de Estudios Hebraicos y Sefardies, 1957, vol. 17/2, pp. 314-351.

31 Val Valdivieso, María Isabel del. "Conflictividad social en la Castilla del siglo XV». Acta Histórica et Archaelogica Medievalia, 2005, vol. 26, pp. 1033-1050. 
ÓSCAR LÓPEZ GÓMEZ

barrio, la comunidad local ${ }^{32}$, la provincia y el reino-, y en el interior de cada nivel existían protestas y demandas que no solían ir dirigidas contra entes abstractos o etéreos, ni contra el sistema, sino contra personas específicas ${ }^{33}$-que no siempre eran omes poderosos, pues las luchas a menudo eran intragrupales, dentro de la élite o en el común-, primando los conflictos en torno a cuestiones económicas o laborales (maestros versus aprendices), los relacionados con la venganza entre familias, los producidos por las soflamas de los clérigos o los que movía la envidia entre vecinos ${ }^{34}$.

Existía también un discurso reivindicativo en las formas de organización artificiales, es decir, en las facciones políticas, en cada bando e parçialidad, y, más generalmente, en todas las estructuras de integración en grupos. Sucedía en las instituciones públicas (regimientos, cabildos de jurados, colegios de escribanos, gremios, cabildos catedralicios) y en las organizaciones privadas (hermandades, cofradías ${ }^{35}$ ), en los linajes y en las facciones que maniobraban al margen de ellas. La confluencia y la confrontación de intereses era tal que lo que definía a la protesta urbana era su carácter caótico y en apariencia irreflexivo y anónimo. Difundidas con la palabra oral más que con la escrita, las censuras eran dúctiles y maleables; sobre todo para las facciones que pretendían hacer uso de ellas.

\subsection{Métodos y espacios de acusación}

Había muchas formas de protestar. Antes de acudir a la violencia se recurría a los rumores, a la creación de programas reivindicativos - a menudo memoriales-, y a requerir asambleas de cortes. Se realizaban carteles y/o pinturas en tono burlesco ${ }^{36}$, se daban sermones escandalosos, se establecían motes difamatorios contra ciertas personas (Álvaro de Luna era conocido en Toledo como el de la triste faz), se recitaban poesías, se cantaban canciones, se dirigían despachos a los regidores ${ }^{37}$ y se realizaban panfletos que eran

32 Oliva Herrer, Hipólito Rafael. «¿Qué es la comunidad? Reflexiones acerca de un concepto político y sus implicaciones en Castilla a fines de la Edad Media». Medievalismo, 2014, vol. 24, pp. 281-306.

33 Esto es fácil de percibir en la concesión de licencias de armas, para cuya solicitud debían indicarse los nombres de las personas a quienes se temía. Gonzalo de Esquivias, por ejemplo, recelaba de un tundidor conocido como San Martín y de otras personas a cabsa de çiertos enojos e diferençias que a tenido con el dicho Sant Martín, disyendo que le ha fecho mucho daño en su fasyenda: AGS, RGS, 1504-VI, Medina del Campo, 22 de junio de 1504).

34 Por ejemplo, posiblemente fueran la envidia y los deseos de venganza los que llevaron a un hombre a asesinar a un porquero en 1484: AMT, ACJ, "Actas capitulares (1470-1478). Cuentas, cartas, varios», caj. 23, reunión del 27 de marzo de 1484, fol. 236r-v.

35 Las protestas, críticas y amenazas entre cofradías eran comunes, tanto por causas económicas como de preeminencia pública. Dos de las cofradías que peor se llevaban en Toledo eran la de la Candelaria, integrada por sastres, y la de los zapateros. El día del Corpus Christi de 1512 llegaron a las manos en la catedral, produciéndose una trifulca cuya resolución acabó en la Chancillería de Valladolid: ARChV, Registro de ejecutorias, caja 302, exp. 17.

36 Véase una de estas pinturas en: Ruiz TaboAda, Arturo y López Gómez, Óscar. "Arqueología e historia de una casa bajomedieval en Toledo». Melànges de la Casa de Velázquez, 2006, vol. 36/1, pp. 195 213. En concreto p. 203.

37 Este fue el método empleado por Cristóbal de Alcocer para quejarse de la actitud irresoluta de los regidores frente a la agresión que había sufrido de parte de Payo de Ribera y sus hombres: AMT, Fondo histórico, Libro de cartas de los siglos XV-XVI, n. ${ }^{\circ} 120$, fols. 34 y 35. 
ÓSCAR LÓPEZ GÓMEZ

250

LA ÇIBDAD ESTÁ ESCANDALIZADA. PROTESTAS SOCIALES Y LUCHA DE FACCIONES

repartidos por las plazas o colgados en las puertas de las iglesias ${ }^{38}$. Se reventaban las reuniones parroquiales con insultos, amenazas y gritos $^{39}$; o se acudía a las asambleas de los dirigentes públicos para impedir su trabajo, y se convocaban juntas alternativas, con el fin de imponer los criterios propios en los más diversos asuntos: relaciones laborales,

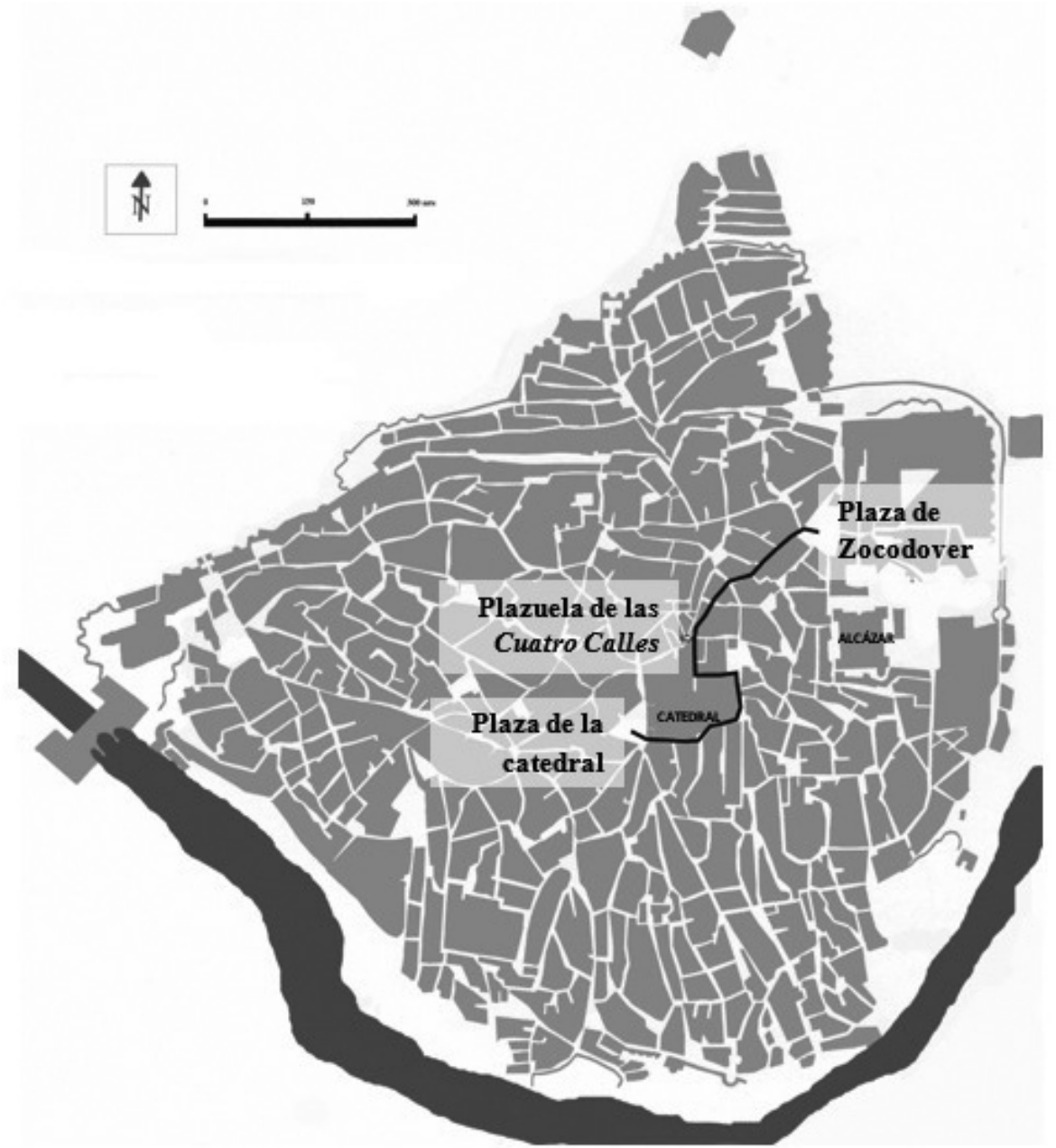

FIG. 1. Calles acostumbradas a fines del siglo Xv (reconstrucción a partir del lienzo de El Greco).

38 Un día de junio de 1519 amaneçieron puestos en çiertos lugares públicos de la dicha çibdad de Toledo quatro cartones, pintados en ellos los dichos ynquisidores ygnominiosamente, metidos y çercados de llamas de fuego. $Y$ a unos demonios en derredor d'ellos. $Y$ debaxo un letrero en que los denuncia [ba]n por descomulgados...: AGS, CC, Cédulas, libro 49, fols. 25r-27v.

39 López Gómez, Óscar. «Representatividad política y rebelión social a finales del Medievo: las asambleas del común en Toledo (1478-1522)». Anuario de Estudios Medievales, 2012, vol. 42/2, pp. 727-753. 


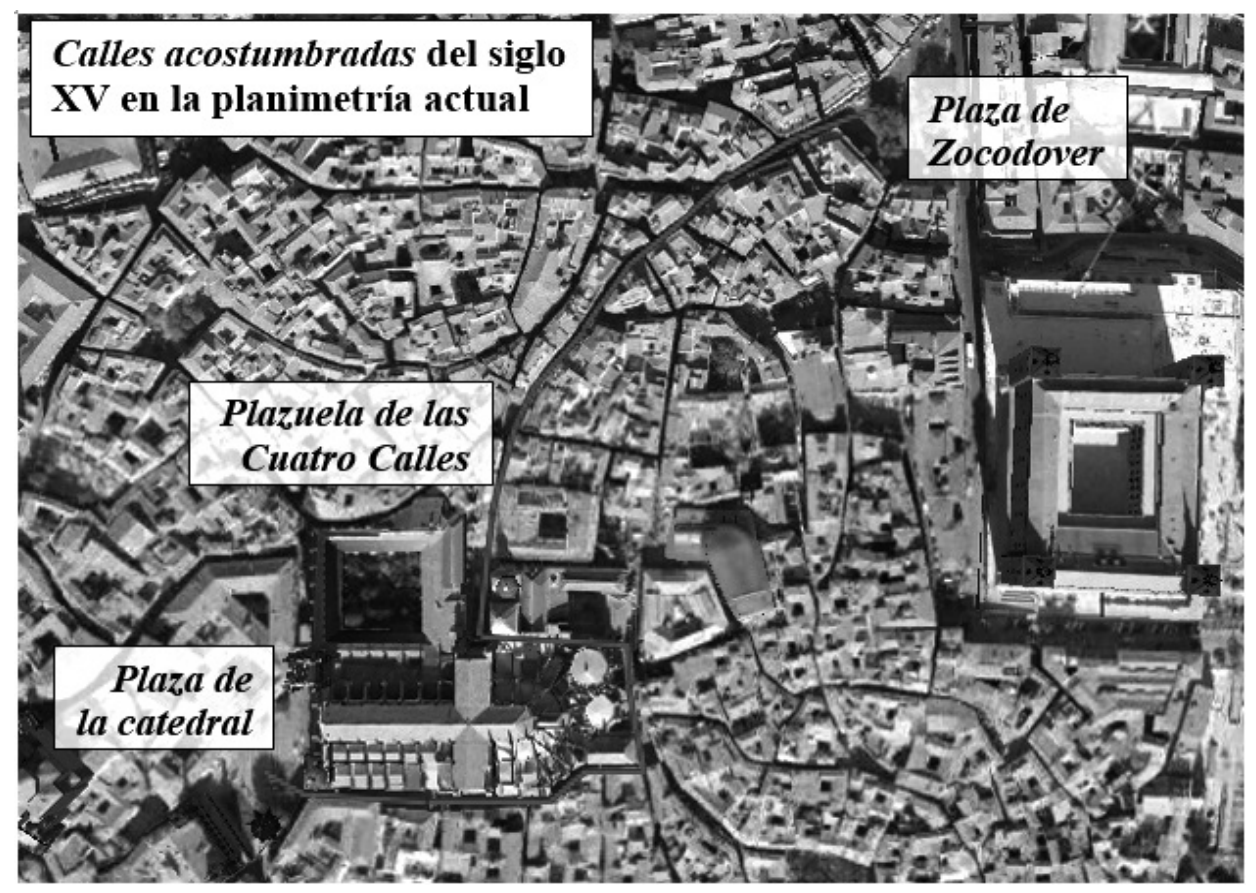

FIG. 2. Calles acostumbradas del siglo xv en la planimetría actual.

rondas de vigilancia, elección de jurados, cobros de tributos, planteamientos políticos, levas de tropas, etc. Las acciones reivindicativas se realizaban de forma individual o entre varios sujetos; desde el anonimato o en nombre de una facción política, un organismo institucional o una de las cofradías.

$\mathrm{Al}$ igual que en el resto de ciudades, en Toledo el ámbito de desarrollo de la protesta pública tenía un lugar privilegiado en las plazas y mercados, y, muy especialmente, en la zona más concurrida; en los alrededores de las calles acostumbradas: un recorrido prefijado que iba desde la plaza del Ayuntamiento a la de Zocodover, en el que la justicia ejecutaba sus sentencias, la Iglesia formalizaba sus actos y las facciones exhibían su poderío. Sobre todo, en tres puntos era notable la difusión de rumores: en las dichas plazas del Ayuntamiento y de Zocodover y, en especial, en la plaça de las Cuatro Calles, zona caliente en lo relativo a la conflictividad, hasta el punto que allí la protesta cobraba un sentido simbólico. Las Cuatro Calles eran el corazón del núcleo urbano; un espacio central entre las plazas principales. Protestar en este punto, reunir en las Cuatro Calles a hombres armados -algo frecuente por parte de las facciones-, tenía una enorme significación. Era dirigirse a la comunidad desde el espacio de convivencia más relevante ${ }^{40}$.

40 Nieto Soria, «El pregón en la vida política», p. 80; LetT, Didier y Offenstadt, Nicolas. «Les pratiques du cri aun Moyen Âge». En Lett, Didier y Offenstadt, Nicolas (dirs). Haro! Nöel!' Oyé! Pratiques du cri aun Moyen Âge. Paris: Publications de La Sorbonne, 2003, pp. 5-41. 
ÓSCAR LÓPEZ GÓMEZ

Más allá de las calles, las palabras escandalosas tenían su ámbito de propagación en las tabernas y mesones, en los conventos ${ }^{41}$, en la iglesia catedralicia y en los palacios de los oligarcas, donde, además, se celebraban juntas secretas, en las que se establecían roles, se negociaba, se definían estrategias, se hacían juramentos y se cantaba y gritaba como símbolo de unión ${ }^{42}$.

\subsection{Las fiestas: tiempos de diversión y critica}

En momentos de especial tensión los rumores y las protestas se enervaban, produciéndose una desazón colectiva ante la idea de que «algo iba a ocurrir». Durante los prolegómenos de una de las revueltas acaecidas en Gante -que se produjo en marzo y abril de 1477, y se extendió por Brujas, Ypres y otras urbes- se decía en el mercado que «estaba incubándose un mal pollo», como advertencia de lo que se avecinaba ${ }^{43}$. Unos años más tarde, en 1481, en una conspiración urdida contra la reina Isabel en Toledo, por las calles se escuchaban algunas discordias [...] algunas sysañas. Aunque las razones que explicarían un complot y el aumento de las tensiones públicas serían siempre complejas, era usual que los dirigentes públicos, en una simplificación rotunda, achacaran las intrigas, las maquinaciones y los escándalos a los alborotadores de pueblos ${ }^{44}$ : a individuos con fines maliciosos que llevados por el egoísmo y la falta de escrúpulos querían hacer triunfar sus deseos de riquezas y poder, aun a costa del bien común. Los cronistas de los reyes culpaban a estos alborotadores de instigar la angustia colectiva que acabó degenerando en revuelta en algunas urbes, siendo el ejemplo paradigmático lo ocurrido en Toledo en 1520, en los prolegómenos del alzamiento de las Comunidades ${ }^{45}$. En unas circunstancias críticas de malas cosechas, subidas de precios, hambrunas y conflictos políticos, los rumores ominosos espolearon la desesperanza colectiva en busca de un único enemigo, fuente de sufrimiento $^{46}$, con el que romper toda relación en aras a ser feliz de alguna manera.

41 AMT, ACJ, «Actas capitulares (1470-1487)», caj. 23, reunión del 12 de marzo de 1481, fol. 115v.

42 López Gómez, Óscar. Los Reyes Católicos y la pacificación de Toledo. Madrid: Castellum, 2008, pp. 60-61.

43 Dumolyn y Haemers, "A Bad Chicken», pp. 45-86.

44 Sin ir más lejos, es evidente la simplificación explicativa dada por los cronistas de los reyes al inicio de la revuelta de 1449 en Toledo. Desde su punto de vista, todo empezó por la actitud insurrecta de un odrero: Benito Ruano, Eloy. Toledo en el siglo XV. Vida politica. Madrid: Consejo Superior de Investigaciones Científicas, 1961, p. 35. Palencia, Alfonso de. Gesta Hispaniensia ex annalibus sucrum dierum collecta, ed. de B. Tate y J. Lawrence. Madrid: Real Academia de la Historia, 1998, tomo I, libro I, cap. 8, p. 28.

${ }_{45}$ Andaban de noche con linternillas disfrazados por las calles de los oficiales y aún de los ciudadanos de más manera, persuadiéndoles a la libertad, y aún de los males y opresiones y pechos intolerables que decian que hauia de hauer, y decian no hauer otro remedio sino hechar de Toledo las justicias y los que sentian en contrario dellos por qualquier vía que fuese posible, y de dia hacian juntar corrillos de sus criados que hablasen y dijesen cosas perjudiciales y de amenazas contra algunas personas principales: MARTínez GiL, Fernando. La ciudad inquieta. Toledo comunera, 1520-1522. Toledo: Instituto Provincial de Investigaciones y Estudios Toledanos-Diputación Provincial de Toledo, 1993, p. 55.

46 Los judíos, en los movimientos sociales de 1391; los judeoconversos, en las revueltas de 1449 y 1467; el rey y sus asesores, en 1520. 
ÓSCAR LÓPEZ GÓMEZ

En este sentido, la catarsis de la desazón comunitaria podía comenzar en un espacio y un tiempo específicos; por lo común en un día de proyección social privilegiado, como lo eran las fiestas. No es casualidad que la mayoría de los tumultos que vivió la ciudad del Tajo en el siglo Xv y a inicios del XVI se iniciasen en una jornada festiva, o en los días siguientes. En los tiempos de ocio los rumores y las actitudes sediciosas se podían extender más fácilmente. El domingo 19 de julio de 1467, por ejemplo, un grupo armado entró en la catedral tras la misa mayor, al grito de ¡mueran, mueran, que no es ésta iglesia, sino congregación de malos e de viles!, porque acababa de publicarse un entredicho por el impago de una gabela ${ }^{47}$. El resultado fueron dos muertos, varios heridos y una angustia social que degeneraría en un motín.

Efectivamente, las actitudes indecorosas solían aflorar en días de ocio. En ciertas alegrías se toleraban las burlas, manteniéndolas controladas, tiñéndolas de estereotipos, soportándolas como un mal menor -caso de las fiestas de locos, carnaval y las celebraciones tradicionales-, de forma que la manera más apropiada de percibir la disconformidad en los festejos es cuando la crítica está vedada, cuando en la fiesta aparecen actitudes que contrastan con el júbilo, que no lo comparten. En función de esto, eran comunes las trifulcas ocasionadas a raíz de la reunión masiva de vecinos, como solía pasar en las solemnidades del Corpus Christi, estimadas peligrosas por los regidores por ser el día de la comunidad ${ }^{48}$.

En otras ocasiones la protesta era individual. Podía ir desde la neutralidad ante los mandatos del ayuntamiento que pedían limpiar las calles y enlucir las fachadas por donde iban a pasar las procesiones, a no asistir a los recibimientos con que se obsequiaba a los reyes, irse a cazar -lo que estaba prohibido en días de fiesta-, ponerse ropas no adecuadas por estatus, vestir de negro y no de rojo, o destruir los decorados que se levantaban para acondicionar el espacio a las festividades; un modo de protestar que solía darse en las noches previas a las actos de celebración ${ }^{49}$. Los regidores, en todo caso, veían con temor, sobre todo, las fiestas organizadas por facciones, hermandades, cofradías o grupos de jóvenes; máxime cuando tenían lugar por las noches, en que a causa de la bebida se escandalizaba la çibdad con gritos y música, tañendo tamborinos ${ }^{50}$, entrando en viviendas de familiares a altas horas ${ }^{51}$, o acudiendo a mesones y mancebías.

47 López Gómez, Los Reyes Católicos y la pacificación de Toledo, p. 65 y ss.

48 Martínez GiL, Fernando. «Furia popular. La participación de las multitudes urbanas en las comunidades de Castilla». En Martínez GiL, Fernando (coord.). En torno a las comunidades de Castilla. Actas del Congreso Internacional "Poder, conflicto y revuelta en la España de Carlos I». Cuenca: Universidad de Castilla-La Mancha, 2002, pp. 309-364. En concreto pp. 326 y 327.

49 El ayuntamiento toledano en ocasiones contrataba a hombres para que, en días de fiesta, por la noche guardaran la ropa [con que estaban forrados los tablados de Zocodover] para que no se faratase: AMT, Fondo Histórico, «Propios y arbitrios. Cuentas de cargo y data del mayordomo», caja n. ${ }^{\circ} 2.120$, data de 1489, libramiento del 15 de enero. Véase: López Gómez, Óscar. «Fiesta y ceremonia del poder regio en Toledo a fines de la Edad Media». En Martínez-Burgos García, Palma y Rodríguez GonzÁlez, Alfredo (coords.). La fiesta en el mundo hispánico. Cuenca: Universidad de Castilla-La Mancha, 2004, pp. 245-279.

50 AMT, «Este libro es de traslados de cartas para los reyes y para otras personas, y para las simples de poca ynportançia. Xv. XvI», Sección B, n. ${ }^{\circ} 120$, fol. 296r-v.

51 IzQuierdo Benito, Ricardo. "La noche de Toledo en el siglo XV». Boletin de la Real Academia de Ciencias Históricas de Toledo, 1994, vol. 30, pp. 123-142. 


\section{ÓSCAR LÓPEZ GÓMEZ

En el área del debate popular, de la opinión pública, la protesta campaba a sus anchas en boca de unos ciudadanos por lo común mal informados ${ }^{52}$. En este entorno confluían las protestas políticas, sociales y laborales con aquellas causadas por motivos privados de distinta naturaleza. Se trataba de corrientes de opinión en principio pacíficas, que permanecían en un estadio infrapolítico a la espera de que se produjese un posible hecho detonador ${ }^{53}$.

En semejante caldo de conflictividad, oculto, clandestino, subterráneo, las fuerzas estatales buscaban imponer su tutela sobre la información, con el fin de evitar el avance de opiniones peligrosas para el orden público ${ }^{54}$. Y lo mismo hacían los bandos e parçialidades, las facciones políticas, si bien con fines diferentes. En un caso y en otro lo que se pretendía era refrenar los instintos, las emociones, las costumbres, en aras a conseguir una comunidad que viviera bajo unos parámetros específicos ${ }^{55}$. Cada organismo de poder buscaba que imperase su criterio (incluida la Iglesia ${ }^{56}$ ), de modo que, más allá de la corriente de protesta contra los abusos de los poderosos que definía al discurso del común $n^{57}$, existían decididos intentos de manipulación por parte de las instituciones y los linajes, los oligarcas y los diferentes grupos políticos ${ }^{58}$.

52 Walker, Simon. «Rumour, Sedition and Popular Protest in the Reign of Henry IV». Past and Present, 2000, vol. 166, pp. 31-65.

53 Sobre la circulación de rumores e información en la Edad Media véase, por ejemplo: WICKHAM, Chris. "Gossip and Resistance among the Medieval Peasantry». Past and Present, 1998, vol. 160, pp. 3-24; Ormrod, W. Mark. «Murmur, Clamour and Noise: Voicing Complaint and Remedy in Petition to the English Crown, c. 1300-c. 1460». En Ormrod, W. Mark y Musson, Anthony (eds.). Medieval Petition: Grace and Grievance. Woodbridge: York Medieval Press in association with Boydell \& Brewer, 2009, pp. 135-155; Verdon, Jean. Information et désinformation au Moyen Âge. Paris: Persin, 2010; Belloré, Maïté y Soria, Myriam (dirs.). La rumeur au Moyen Âge. Du mépris à la manipulation ( $V^{\ell}-X V^{e}$ siècle). Rennes: Presses Universitaires de Rennes, 2011.

54 Petrucci, Armando. «Potere, spazi urbani, scriture esposte: proposte ed esempi». En Culture et idéologie dans la genèse de l'État Moderne. Actes de la table ronde organisée par le Centre National de la Recherche Scientifique et l'École française de Rome, Rome, 15-17 octubre 1984. Paris: École Française de Rome-Palais Farnèse, 1985, pp. 57-84.

55 BAzÁn DíAz, Iñaki. «Sy fuere villano que lo enforquen por ello, e sy fuere fijodalgo que le enposen fasta que muera. La pena de muerte en la legislación vasca medieval». En González Mínguez, César y BAzÁN DíAz, Iñaki (dirs.). El discurso legal ante la muerte durante la Edad Media en el nordeste peninsular. Guipúzcoa: Universidad del País Vasco, 2006, pp. 291-423. En concreto pp. 301-302. Lop Otín, María José y López Gómez, Óscar. «Entre la paz y el caos. Acción subversiva y actividad pacificadora en las élites urbanas del siglo xv: Toledo, 1441-1495». Hispania [en prensa]. 1990.

56 Menache, Sophia. The Vox Dei. Communication in the Middle Ages. Oxford: University Press,

57 No está claro si en algunos casos la protesta pechera obedece a la ideología del común o a los intereses del clientelismo oligárquico. Montero Málaga, Alicia Inés. «Vecindades y procuradores, protesta y conflicto en Burgos: ¿verdadero discurso del común o expresión del clientelismo nobiliario?». Comunicación dada en la XXVII Asamblea General de la SEEM. Congreso Internacional Formas de protesta, movilización y lucha politica...

58 La manipulación de los conceptos políticos era clara. Ocurría especialmente con el concepto bien común (JARA Fuente, José Antonio. «Legitimando la dominación en la Cuenca del siglo Xv: la transformación de los intereses particulares a través de la definición del bien común». Anales de la Universidad de Alicante, 
ÓSCAR LÓPEZ GÓMEZ

Uno de los casos más feroces de manipulación de la opinión pública se padeció en Toledo entre 1504 y 1507. El marqués de Villena, Diego López Pacheco, y su aliado, el conde de Fuensalida, Pedro López de Ayala, sembraron el pánico con una actitud terrorista, hasta el punto de matar a varios individuos, entre ellos un gobernante de la segunda oligarquía -no un caballero-: el jurado Diego Terrín. El objetivo era sembrar el caos, instaurar una sensación de incertidumbre, de miedo ante el futuro. Con la violencia desplegada por sus hombres querían advertir a la comunidad de que iba a pasar algo grave, puesto que su corregidor, Pedro de Castilla, era un incompetente, como atestiguaba su incapacidad para impedir los crímenes que, sin apenas disimulo, estaban ejecutando los esbirros del marqués e el conde. Había que desacreditar al corregidor para que, perdidos los apoyos sociales, tuviese que dejar el puesto en manos de sus enemigos ${ }^{59}$. Se trataba de una estrategia para someter a la urbe, que no era nueva, pues se venía dando desde el siglo $\mathrm{XIV}^{60}$, pero que resulta llamativa por los datos que hay sobre su desarrollo, evidencia de la acritud que podían alcanzar los reproches cuando eran poderosos quienes los alimentaban.

Los caballeros, y en general las parcialidades políticas, fomentaban una guerra de rumores, improperios, críticas y alegatos que a menudo solían implicar a la población en su conjunto, a fin de amedrentarla, por un lado, y ganársela para su causa, por otro $^{61}$. De igual forma, con los rumores y los escándalos se pretendía calibrar la reacción del pueblo y de los rivales, para así imponer unas líneas rojas, unos límites. Gracias a la disputa infrapolítica en torno a las informaciones difundidas, cada parçialidad buscaba definir su espacio de acción, frente a lo que algunos gobernantes respondían con contra-propaganda y gestiones concretas ${ }^{62}$, como mantener las calles limpias, los mercados abastecidos y los precios en niveles asumibles; impedir la presencia de malhechores y vagabundos; la ejecución ejemplar de la justicia; la asistencia a los necesitados; la construcción y el mantenimiento de las murallas, puentes, calzadas y caminos; o la contratación de médicos o boticarios. Se trataba de tareas por el bien común con que los dirigentes pretendían crearse una imagen bondadosa ${ }^{63}$, la cual, sin embargo, era torpedeada por la rumorología y la violencia. En Toledo las amenazas de desórdenes eran constantes; parecía que se estuvieran preparando motines a todas horas. Así lo alegaba un corregidor en abril de 1516, quien, harto de avisos sobre ofensivas inminentes,

2009-2012, vol. 16, pp. 93-119) y con el concepto paz (López Gómez, Óscar. «Pas e sosyego. Un argumento de acción política en la Castilla bajomedieval». Medievalismo, 2006, vol. 16, pp. 41-71).

59 López Gómez, Óscar. «Después de Isabel la Católica: la reaparición de la lucha de facciones en Toledo». Anales de la Universidad de Alicante, 2012, vol. 18, pp. 315-343.

60 López Gómez, Óscar. «Abusos de poder y desacato a la justicia en el ámbito urbano medieval: Toledo (1085-1422)». Historia. Instituciones. Documentos, 2005, vol. 32, pp. 211-245. En concreto pp. 233 y ss.

61 Monsalvo Antón, José María. La Baja Edad Media en los siglos XIV-XV. Política y cultura. Madrid: Síntesis, 2000, p. 50.

62 Lecuppre-Desjardin, Elodie. «Proclamar la autoridad, afirmar el poder, reducir al pueblo: una reflexión sobre la comunicación política en los antiguos Países Bajos borgoñones». Edad Media. Revista de Historia, 2012, vol. 13, pp. 103-121.

63 Martín Cea, Juan Carlos y Bonachía Hernando, Juan Antonio. «Oligarquías y poderes concejiles en la Castilla bajomedieval: balance y perspectivas». En Narbona Vizcaíno, Rafael (comp.). Oligarquías politicas y élites económicas en las ciudades bajomedievales (siglos XIII-XVI), Revista d'Historia Medieval, 1998, vol. 9, pp. 17-40. En concreto p. 33. 
ÓSCAR LÓPEZ GÓMEZ

resolvió una advertencia en torno a una posible rebelión alegando que no se debía dar crédito, pues éstas heran las cosas de Toledo ${ }^{64}$.

\subsection{Antes de los alborotos: los discursos de permanencia, modificación y cambio}

En la urbe chocaban dos líneas de pensamiento: una de carácter conservador, por la que apostaban la ricahombría y la clase alta de los caballeros (discurso de permanencia ${ }^{65}$ ); y otra que solicitaba reformas, definida por su heterogeneidad, donde cabían sensibilidades variadas, que iban desde la de quienes -en la élite del común y la baja caballeríarequerían innovaciones institucionales para salir favorecidos (discurso de modificación ${ }^{66}$ ), hasta la de aquellos otros que, en la miseria, querían que se instaurase una sociedad más igualitaria, donde la riqueza se repartiese mejor (discurso de cambio ${ }^{67}$ ). Los pecheros, por lo tanto, no presentaban una actitud de protesta unívoca ni un discurso homogéneo. $\mathrm{Al}$ igual que el común se especificaba por su diversidad, así lo hacían sus argumentos. No obstante, en los preámbulos de un alboroto la polifonía de los discursos podía quedar reducida a principios simples y apasionados, sintetizables en gritos y eslóganes. Aunque algunas revueltas arrastraron interesantísimos debates teóricos, que contarían con la participación de célebres intelectuales ${ }^{68}$, con frecuencia una de las primeras víctimas en los alzamientos era la cultura de la deliberación que los había alimentado, no solo porque se redujese la riqueza de los discursos merced a simplificaciones burdas, sino porque, además, cuando la çibdad se alborotaba se producía una restricción inmediata de la opinión pública. En medio de toda clase de rumores -en Toledo habitualmente

64 AGS, Secretaría de Estado, leg. 1 (2), doc. 443.

65 En una concordia lograda el 12 de diciembre de 1506 los líderes de las facciones de Toledo, temerosos de que sus conflictos degenerasen en una sublevación colectiva, ponían por escrito algunas de las ideas que legitimaban este discurso conservador, al puntualizar que, independientemente de sus disputas, como élite no podían permitir que los omes poderosos fueran muertos por los hombres de baja suerte malamente: López GómEz, Violencia urbana y paz regia, pp. 1292 y ss.

66 Este discurso es el que favoreció la creación del Cabildo de jurados en 1422. Véase al respecto: Aranda Pérez, Francisco José. «Privilegio de Juan II por el que se crea, junto al Regimiento, el Cabildo de jurados de Toledo, a imitación del de Sevilla». Beresit, 1992, vol. 4, pp. 51-55; Ídem. Poder municipal y Cabildo de Jurados en la Edad Moderna (siglos XV-XVIII). Toledo: Ayuntamiento de Toledo, 1992.

${ }_{67}$ Este discurso ha sido remarcado por el profesor José María Monsalvo AnTón, sobre todo a raíz de un trabajo sobre los pecheros abulenses y salmantinos: «Ideario sociopolítico y valores estamentales de los pecheros». En el caso de Toledo, los documentos permiten leer entre líneas un ideario similar al propuesto por Monsalvo Antón. De hecho, fue la confluencia entre el discurso de cambio de los pecheros y el discurso de modificación de la élite del común la que favoreció la creación de una institución popular tan interesante como la Congregación durante la revuelta de las Comunidades de Castilla: Martínez GiL, La ciudad inquie$t a$, pp. 149-155. La creación de instituciones populares con un fondo de estructura igualitaria también se había dado en la revuelta de 1449, en la que se instauró un organismo considerado la antesala de la Inquisición, al que Benzion Netanyahu dedicaría parte de su obra magna Los orígenes de la Inquisición en la España del siglo XV. Barcelona: Crítica, 1999.

68 Como pasó en la revuelta toledana de 1449: López Gómez, Óscar. «El impacto de las revueltas urbanas en el siglo xv. A propósito de la rebelión de 1449 en Toledo». Edad Media. Revista de Historia, 2014, vol. 15, pp. 173-190. En concreto pp. 186-187. 
ÓSCAR LÓPEZ GÓMEZ

en torno a la reunión de hombres y arsenales en las viviendas de los poderosos- la población corría a poner sus bienes a buen recaudo (en capillas, parroquias, conventos, la catedral), procuraba no salir a las calles y, de hacerlo, se cuidaba de transitar por sitios donde solían apostarse omes armados y de hablar más de la cuenta (había espías; en ocasiones niños contratados para oler qué se hablaba $\left.{ }^{69}\right)$. Las facciones favorecían esta situación de incertidumbre con sus actos y pregones, en los que pedían que reinase la paz que deseaban, aunque hubiese que recurrir a la fuerza ${ }^{70}$. Pero también lo hacían las autoridades con sus medidas tendentes a acallar a la opinión pública, estableciendo una rápida pacificación mediante toques de queda, la proscripción de las armas o los pregones prohibiendo los discursos escandalosos so pena de muerte ${ }^{71}$. En cualquier caso, calmar las protestas era difícil cuando la çibdad estaba alborotada.

Era muy común que en los preámbulos de un alboroto apareciesen dos categorías de mensajes: una más oficial, basada en una reflexión más o menos concienzuda, acordada y definida por quienes pretendían ser los líderes del tumulto $^{72}$, fueran los cabecillas de una facción o los integrantes de la élite pechera -mercaderes, profesionales liberales, maestros artesanos-; y otra directa, menos teórica y más informal, llena de amenazas e insultos ${ }^{73}$, propia de las clases bajas y jóvenes sin trabajo ${ }^{74}$, de mançebos no aún experimentados en los males de las guerras e escándalos, e engañados por promesas e esperanzas inciertas; otros muchos que çiegos de ynorançia son traidos do no les cumple; otros vençidos del pecado de la cobdiçia, creyendo enrriqueçer en çibdad turbada con robos e fuerças.

Una de las razones que explica los conflictos en las urbes es la mezcolanza de discursos mesurados, aunque de carácter reivindicativo, con los que apostaban por la rebelión abierta $^{75}$. En esta disputa las élites perseguían las ideas más extremas, puesto que su plasmación podía traer resultados imprevisibles. A los líderes de las facciones les asustaba la posibilidad de que el común se rebelase sin su beneplácito y, ciego por la furia, matara

69 El proceso contra Juan Gaitán. Toledo: Carmen Vaquero, 2002, pp. 345-348.

70 Uno de estos pregones fue dado en noviembre de 1471 por los Silva, en contra de los Ayala: AMT, AS, ala. 2. ${ }^{\text {, leg. }} 6 .^{\circ},{ }^{\circ}{ }^{2}$, fols. 91 r-92r.

71 El viernes 7 de abril de 1475 se dio en Toledo un pregón que advertía que en adelante ninguna persona fuese osada de faser nin mover escándalos, nin andar diciendo otras cosas por las quales se puedan mover los dichos escándalos, porque d'ello vernía deservicio a los Señores Rey e Reyna [...] e grand daño en toda esta çibdad, so pena de muerte... A pesar de su rotundidad, parece indiscutible que las protestas tuvieron un éxito inmediato, pues apenas unos días más tarde, el 25 de abril, los reyes se verían obligados a ratificar el perdón otorgado por Enrique IV en 1468 para frenar la acción de sus oponentes: AMT, AS, caj. 5.․ leg. 6.․ n. ${ }^{\circ}$ 2; Benito RuAno, Toledo en el siglo XV, doc. 80, pp. 287-288.

72 Lop Otín y López Gómez, «Entre la paz y el caos», pp. 420-422.

73 El 9 de marzo de 1467 Gutierre de Huete, canónigo y vicario de la catedral, comunicó a su Cabildo que le habían denunciado un caso de injuria sufrido por unos religiosos. Tras llevar a cabo una pesquisa, puso un entredicho y los regidores le ordenaron que lo alzase. Puesto que se negó, el mariscal Payo de Ribera le hizo una amenaza, advirtiéndole que haría que diesen las canpanas, e llamasen las parrochas, et fuesen contra los clérigos. La amenaza se cumpliría unos meses después: ACT, Actas capitulares, Libro $1 .^{\circ}$, desde el 13 de agosto de 1466 al 27 de mayo de 1490, reunión del 13 de marzo de 1467, fol. 5v.

74 Pulgar, Crónica de los Señores Reyes Católicos, vols. LXVIII y LXX, pp. 340-351.

75 En la revuelta del verano de 1467 se puede comprobar esto con claridad. Desde la primavera se produjo una radicalización de los discursos que degeneró en una violencia colectiva de un simbolismo indiscutible. Véase al respecto: López Gómez, Los Reyes Católicos y la pacificación de Toledo, pp. 54-71. 
ÓSCAR LÓPEZ GÓMEZ

a personas de la oligarquía ${ }^{76}$. La contundencia del discurso radical podía oscurecer los discursos prudentes, como sucedió en 1449, lo que no impediría que el mensaje que terminara imponiéndose en perspectiva histórica fuese el sosegado. En el único ámbito en que triunfó el mensaje radical fue en el antisemitismo, según han señalado historiadores como Benzion Netanyahu y David Nirenberg. Y, si pasó así, fue porque el propio lenguaje antisemita fue empleado por las facciones en su beneficio, porque su uso perseguía fines de carácter económico (y no puramente religioso ${ }^{77}$ ), y porque el antisemitismo se envolvió de conceptos que también sufrirían la manipulación de la Iglesia ${ }^{78}$.

En todo caso, era habitual que en los alborotos las protestas infrapolíticas que se venían desarrollando desde hacía meses o años quedasen reducidas a principios simples, populistas, radicalizados y demagógicos. Antes del escándalo el lenguaje subversivo se formulaba susurrando, jurando o disputando en las juntas políticas o las parroquias. Una vez que la asonada era un hecho, la mesura era sustituida por gritos y bravuconerías. En Flandes el lenguaje más radical se hallaba en boca de inmigrantes, pobres y jóvenes, que vociferaban frente a sus contrarios: ¡Matadlos! ¡Matadlos! ¡Hijos de puta! ${ }^{19}$. En los inicios de las sediciones la atmósfera pasional empujaba a los excesos y, a medida que arreciaba la aspereza de los discursos, se hacían más intimidantes los gritos, los insultos (el de ¡traidores! era habitual ${ }^{80}$ ) y las consignas que enardecían el ánimo de los rebeldes ( Viva el pueblo! ¡Comunidad! ¡Libertad!). El origen de no pocas sublevaciones habría que situarlo ahí: en el llamamiento a la lucha realizado mediante consignas y/o insultos, a voces. En la lucha banderil se gritaba el nombre de la parcialidad para movilizar a su clientela ${ }^{81}$, si bien el radicalismo del discurso podía superar los límites impuestos por las convencionalidades oligárquicas, dirigiéndose indiscriminadamente contra judíos y judeoconversos, omes poderosos, ricos, malos gobernantes y clérigos disolutos. Se apelaba a ideas emotivas

76 El 12 de diciembre de 1506 Silvas y Ayalas llegaron a un acuerdo para que, en caso de pelea, emplearan solo ciertas armas. El pacto se legitimó con este argumento: aunque en esta cibdad ha habido muchos movimientos y alteraciones, nunca Nuestro Señor permitió que en ellos muriese alguna persona principal, de cuya causa oviera habido entre los caballeros desta cibdad enemistades perpetuas, según vemos que ha acontecido y dura hoy en muchas cibdades destos reinos. Y pues Dios lo hizo hasta aqui maravillosamente, y porque esto dure para siempre, y porque los buenos caballeros y escuderos y los buenos sean conocidos por tales y no sean muertos por los hombres de baja suerte malamente...: AMT, AS, caj. 1. ${ }^{\circ}$, leg. 1. ${ }^{\circ}, \mathrm{n}^{\circ}$. 27; BNM [Biblioteca Nacional de Madrid], Mss. 13.112, fols. 43r-48v.

77 Mollat y Wolff, Uñas azules, pp. 7 y ss.

78 Arranz Guzmán, Ana. «Excomunión eclesiástica y protesta ciudadana». En Nieto Soria, José Manuel (dir.). El conflicto en escenas. La pugna política como representación en la Castilla bajomedieval. Madrid: Sílex, 2010, pp. 211-246. En concreto pp. 226-227.

79 Dumolyn y Haemers, "A Bad Chicken», p. 78.

80 ¡Traidores! era el insulto más escuchado en la revuelta toledana de 1467 contra los conversos: RAH, Colección Salazar y Castro, sig. N-4, fol. 200r. Challet, Vincent. "Moyran, los traidors, moyran. Cris de haine et sentiment d'abandono dans les villes languedociennes à la fin du XIV siècle». En LeCuppre-Desjardin, Elodie y Van Bruaene, Anne-Laure (eds.). Emotions in the Heart of the City (14 $4^{\text {th }}-16^{\text {th }}$ Century): studies in European Urban History (1100-1800). Turnhout: Brepols, 2005, pp. 83-92.

81 En Toledo, ¡Silva! y ¡Ayala!; en Valladolid, ¡Reoyo! y ¡Tovar!: Martín Romera, María Ángeles. «Bandos, violencia y altercación de la paz pública en las ciudades bajomedievales: el caso de Valladolid». En Arranz Guzmán, Ana; Rábade Obradó, María del Pilar y Villarroel González, Óscar (coords.). Guerra y paz en la Edad Media. Madrid: Sílex, 2013, pp. 163-187. En concreto p. 176. 
ÓSCAR LÓPEZ GÓMEZ

relacionadas con la fe y la supervivencia; ideas a menudo erróneas que producían miedos y dudas sobre lo que estaba pasando en la urbe ${ }^{82}$, donde al parecer ciertos individuos conspiraban para subyugar al pueblo.

\subsection{Las ceremonias del escándalo}

De forma paralela a la radicalización de los discursos las facciones pasaban de las palabras a los hechos, cobrando fuerza la violencia y sus ritos, los cuales, realizados en las casas de los líderes de la parçialidad, en plazas o en iglesias, poseían un doble carácter: positivo, consistente en rendir homenaje, reunirse, hacer una jura y gritar la posición del grupo al unísono; y negativo, en torno a ideas de evitación, distanciamiento y prohibición.

Las asambleas de las facciones se hacían en privado, si bien su proyección pública era inmediata. Los líderes se reunían con los representantes de su clientela -en ocasiones ante notario- y establecían su postura, ratificándola con juramentos y gritos de unidad, como puede observarse en la junta celebrada en el palacio del conde de Cifuentes el 18 de abril de $1467^{83}$. En las horas previas se habían remitido emisarios a las casas de los jefes de la facción, quienes a su vez habían movilizado a sus hombres para reunir a una clientela nutrida en la vivienda de su líder. Faltar a un ritual como ese habiendo sido avisado era una afrenta que se podría tachar incluso de traición ${ }^{84}$. Y así, reunido un buen número de individuos, en la asamblea primero habló el líder, y luego el resto de cabecillas de la parcialidad. Se trataba de una especie de ceremonia laica, política, que serviría para definir una posición común, regular las emociones y -de darse el caso- encender la ira. El propio escenario (la vivienda del líder) poseía un carácter simbólico, lo que unido a la calidad dramática de los gestos y los discursos buscaba una respuesta emocional en los participantes ${ }^{85}$, unificando la diversidad de posturas hacia una unívoca, que más tarde sería revelada a los enemigos gracias al envío de heraldos, o con pregones. Salvando las diferencias, estamos, sin duda, ante un antecedente remoto de los mítines que organizan hoy los partidos políticos.

Una vez todos conocían su misión, debían proceder en sus respectivos ámbitos de influencia. Y solo, si la postura no lograba imponerse, se exigiría más presión en las instituciones y el impulso de las actividades subversivas al margen de ellas. Empezaría así lo que Angus Mackay denomina una «agresión ritualizada», una lucha ficticia y sin sangre, con reglas y compatible con la acción institucional. Se trataba de una conflictividad pautada que a menudo conseguía sus fines, pues el miedo ocasionado por las protestas y las manifestaciones de poder servía para remediar los conflictos ${ }^{86}$. En los alardes banderiles

82 Téllez Aguilera, Abel. La delincuencia de las muchedumbres. (Estudio criminológico y jurídicopenal de la muchedumbre criminal). Madrid: Universidad de Alcalá de Henares, 1991, p. 9.

83 López Gómez, Los Reyes Católicos y la pacificación de Toledo, pp. 60-61.

84 Madero, Marta. Manos violentas, palabras vedadas: la injuria en Castilla y León (siglos XII-XV). Madrid: Taurus, 1992, p. 94.

85 Haemers, Jelle. "A Moody Community? Emotions and Ritual in Late Medieval Urban Revolts». En Lecuppre-Desjardin y Van Bruaene (edits.), Emotions, pp. 73-74 y 81.

86 Mackay, Angus. "La conflictividad social urbana». En Las ciudades andaluzas (siglos XII-XVI). Actas del VI Coloquio Internacional de Historia Medieval Andaluza. Málaga: Universidad, 1991, pp. 509-524. 
ÓSCAR LÓPEZ GÓMEZ

era menos trascendente lo que se exhibía - omes armados, pendones, banderas, caballos, ballestas, artillería - que lo que a priori quedaba oculto, aunque no existiera. Eran más relevantes la amenaza y el amedrentamiento que la realidad del poder exhibido, el cual debía manifestarse como una muestra mínima de la fuerza de la facción.

En la agresión ritualizada las facciones procedían de diferentes formas, en un difícil equilibrio entre secretismo y publicidad, cuya meta era promover rumores que contribuyesen a sus fines. Se reunían arsenales, se ocupaban edificios estratégicos - puertas y portazgos, parroquias, torres-, se enviaban emisarios a los señoríos para advertir a los vasallos, se ponían bajo control las barcazas que servían para cruzar el río -con el fin de impedir visitas desagradables-, se presionaba al Ayuntamiento para que no coartase la osadía de la facción rebelde, se daban pregones subversivos en plazas y calles (y discursos en los púlpitos de las iglesias), empezaban a actuar espías para conocer las repercusiones de lo que estaba pasando y, lo más revelador, comenzaban a reclutarse individuos para asistir a la parçialidad insurrecta.

Como culmen del protocolo subversivo en ocasiones se celebraba un desfile de la insubordinación en el que el líder del grupo, escoltado por sus cabecillas, se ponía al frente de su clientela armada y, con pendones, banderas y tambores, escribanos y pregoneros, se echaba a la calle, recorriendo las zonas más transitadas en medio del estruendo provocado por una turbamulta que solo callaba cuando debía darse un pregón (junto a una iglesia, en una plaza o donde hubiera gente). A menudo los líderes de la parçialidad iban con varas de justicia, simbolizando que ellos tutelaban a la población; no las autoridades establecidas. Unas autoridades que en ocasiones también hicieron uso de semejantes actos multitudinarios con opuesto fin ${ }^{87}$ : para sosegar las protestas, rodeándose de centenares de vecinos. No obstante, se trataba de una técnica pacificadora comprometida. Ante réplicas tan rotundas a la labor de las parcialidades era factible que acabara por provocarse una guerra, así que era fácil ver a jurados, procuradores o sexmeros (uno de cuyos cometidos era garantizar el orden) haciendo lo posible por impedir que se contestase a una procesión subversiva sacando más hombres a la calle.

Las procesiones de la insurrección eran otro mecanismo para escandalizar al pueblo, entre los que también destacaba el abandono de las reuniones de forma exteriorizada, es decir, saliendo a las puertas de los edificios en que se estuviera tratando cualquier cuestión -una parroquia, el ayuntamiento-, con amas o sin ellas, para evidenciar que lo que estaba negociándose no tenía el beneplácito de los de fuera. Se trataba de una táctica propia de parcialidades (para presionar a las instituciones), también manejada por los

87 Cuando en 1478 «çibdadanos pacíficos e de buen deseo» aconsejaron al corregidor Gómez Manrique que, si no quería perder el control de la ciudad para Isabel y Fernando, abasteciera las torres y el alcázar y se preparara para resistir hasta que los reyes le enviasen ayuda, pues se había preparado una conspiración, se negó diciendo que no entendia retraerse a ninguna parte de la çibdad para se defender, ni conoçía lugar fuerte ni defendible al pueblo della, porque toda era fortaleza, e el pueblo della era el alcaide, e quando el pueblo era conforme a la rebelión ninguna defensa podía aver en parte de la çibdat. Pero que como quier que él conoçía estar el pueblo della alborotado, creýa bien que avía dos mill onbres que fuesen leales, e lo que él entendia de hacer era ponerse con el pendón real en la plaça, e que con aquellos leales que se allegasen a él, e al pendón real con las armas del Rey, avía deliberado de pelear por las calles de la çibdat contra todos los otros alborotadores e desleales...: López Gómez, Los Reyes Católicos y la pacificación de Toledo, pp. 224-225. 
ÓSCAR LÓPEZ GÓMEZ

representantes del común -con ella querían hacer partícipe de sus posturas al pueblo ${ }^{88}$-, cuya utilización degeneraría a veces en la toma de puntos estratégicos, donde se parapetaban sujetos listos para la lucha, aunque su finalidad no fuera esa, sino exhibir el poder y coaccionar a los enemigos. Un fin idéntico al de las procesiones de protesta organizadas por las parcialidades, quienes igualmente, con fines amenazadores, solían congregar a sus partidarios en iglesias, conventos o plazas.

\section{3 ...oyeron la grita de la gente, cómo ya se levantaba la dicha ciudad...}

La mayoría de las veces la movilización social en los alborotos afectaba solo a las clientelas de las parcialidades. Sin embargo, en ocasiones el movimiento era absoluto, e implicaba a la comunidad, que no siempre asumía los mensajes que le llegaban «desde arriba». Al contrario, la visión del común acerca de los caballeros a menudo era terrible; «la idea de agravio estaba [...] enormemente arraigada en la mentalidad de los pecheros», quienes, acatando la división estamental, detestaban la prepotencia y arrogancia de los patricios ${ }^{89}$. Según James C. Scott, los grupos subalternos, operando en oposición a la ideología dominante, crearon un lenguaje político propio que solía subsistir oculto, y la población nunca interiorizó totalmente la ideología dominante. En general las opiniones de los pecheros se encontraban en algún territorio entre la insurrección y la aquiescencia asumida ${ }^{90}$. Georges Rudé señalaba en esta misma dirección que en el pasado existía una «ideología de protesta popular» que no era propiedad de un grupo, y que se establecía a partir de dos elementos: uno tradicional e inherente, una «especie de leche materna ideológica», basada en la experiencia directa, la tradición oral y la memoria colectiva; y otro cúmulo de ideas y creencias derivadas de las actuaciones de los demás, que a menudo se definían en forma de un sistema estructurado de ideas políticas o religiosas ${ }^{91}$. Cada individuo interpretaba las cuestiones sobre la identidad histórica y política en relación con sus intereses y su sitio en la sociedad ${ }^{92}$, y quienes sufrían el poder reaccionaban de tres modos: acatando con obediencia los dictámenes de los regidores, oponiéndose de forma más o menos clara (si bien no cuestionando el orden vigente), o a través de la revuelta y la insurrección, de no existir alternativas.

Del análisis de las tres grandes revueltas acaecidas en Toledo a fines del siglo XV e inicios del XVI (en 1449, 1467 y 1520) se deduce que las rebeliones-rompimientos o

88 Así ocurrió el 19 de octubre de 1506: AGS, RGS, 1506-XI, Burgos, 21 de noviembre de 1506; AMT, ACJ, DO, n. ${ }^{\circ}$ 78; Martín Gamero, Antonio. Historia de la ciudad de Toledo, sus claros varones, sus monumentos. 2 vols. Toledo: Imprenta de Severiano López Fando, 1862 (edic. facsímil, Toledo, 1979), vol. 2, pp. 924-936.

89 Monsalvo Antón, «Ideario sociopolítico y valores estamentales de los pecheros», p. 339.

90 Scotт, James C. Domination and the Arts of Resistance: Hidden Transcripts. Michigan: Yale University, 1990.

91 Rudé, Georges. Revuelta popular y conciencia de clase. Barcelona: Crítica, 1981.

92 Ladero Quesada, Miguel Ángel. «Proyecto político y grupos sociales en la España de los Reyes Católicos». En Lecturas sobre la España histórica. Madrid: Real Academia de la Historia, 1998, pp. 71-112. En concreto p. 83. 
ÓSCAR LÓPEZ GÓMEZ

movimientos- compartían con las luchas de facciones su "carácter ritualizado", si bien eran menos sistemáticas, más caóticas. Los movimientos frecuentemente se desencadenaban a raíz de lo que era visto por el común como una agresión comunitaria; a uno de sus integrantes o a los privilegios instituidos. Sin embargo, para que la violencia colectiva se desatase eran necesarios dos factores: el llamamiento a gritos o mediante el tańer de las campanas; y la existencia de unos líderes reconocidos por la comunidad, capaces de asumir el liderazgo de la rebelión ${ }^{93}$.

Frente a los cabecillas reconocidos, adalides que contaban con enormes clientelas (caso de Pedro López de Ayala IV, I conde de Fuensalida, y Alfonso de Silva, II conde de Cifuentes), había líderes populares que fascinaban al común con sus discursos enardecidos $^{94}$. A nivel europeo los más famosos son los clérigos británicos John Ball y John Wrane, el campesino francés Guillermo Cale, o Juan Ziska, en Bohemia. En lo referido a Toledo los líderes populares irían desde algunos célebres, como Pero Sarmiento, Juan de Padilla o María Pacheco, a otros menos famosos fuera de la urbe, que sin embargo en ella dejarían su impronta, como los canónigos Pero López de Gálvez y Juan Alonso, con un papel decisivo en la revuelta de 1449; o ya en 1520 Valbuena, el maestro Quiles y el monje agustino fray Juan de Santamarina, el mayor escandaloso y alborotador que andaba en toda la dicha ciudad; rrebolbedor de pueblos ${ }^{95}$.

Una vez que un miembro de la comunidad clamaba en las calles por su ayuda, era frecuente que se repicaran las campanas de alguna parroquia; y la población acudía a las armas, para, inmediatamente, dirigirse a los lugares establecidos por la tradición, donde los líderes exhortaban a la lucha y daban las primeras órdenes sobre cómo proceder. Los «movimientos» a desarrollar en los inicios de un motín estaban pautados: obedecían a la tradición instaurada, a una coreografía establecida por la costumbre. Por ese motivo, las autoridades veían con recelos el tañer de las campanas, hasta tal punto que en las Cortes de 1462 se decretó pena de muerte para quienes las tocasen sin un mandato de la justicia o de los regidores. Por su culpa en unos instantes el silençio (símbolo metafórico de la paz) era roto por ruidos e escándalos, por el estruendo de quienes se lanzaban a la defensa de la comunidad.

En 1520, por ejemplo, al inicio de las Comunidades, en Toledo muchos presenciaron la grita de la gente -cómo ya se levantava la dicha ciudad-, y cómo, apenas reunido un grupúsculo en la plaza de la catedral, se dirigía a la vivienda del corregidor:

Y que cargó la gente de la comunidad hacia la puerta del corregidor, debajo de las ventanas de su casa, y comenzaron a dar voces, y gritos y alaridos, diciendo: « Comunidad, Comunidad!, ;Libertad, libertad!». Y que esto decían los cardadores y zapateros ${ }^{96}$.

93 Dacosta, Arsenio. «Violencia banderiza y escritura histórica: un estudio comparado». En FernáNDez de Larrea, Jon Andoni y Díaz de Durana, José Ramón (eds.). Memoria e historia. Utilización política en la Corona de Castilla al final de la Edad Media. Madrid: Sílex, 2010, pp. 101-140. En concreto p. 119.

94 El fanatismo que despertaban se ha llegado a considerar precursor del fenómeno nazi: FourQUIN, Guy. Los levantamientos populares en la Edad Media. Madrid: DAF, 1979, p. 30.

95 El proceso contra Juan Gaitán, p. 203.

96 Ibidem, pp. 186-187. 
ÓSCAR LÓPEZ GÓMEZ

Una vez que las protestas pasaban de las palabras a los hechos, el lugar de concentración más relevante para el común en el momento de iniciar la lucha era la plaza de la catedral, junto a la Puerta del Perdón, enfrente del ayuntamiento. Al igual que en época de las Comunidades, también allí se aglutinaría una turbamulta de hombres armados al inicio de la revuelta de 1449 , tras el tañido de las campanas causado por las voces de un odrero al que, de forma injusta, se le pedían ciertas doblas $^{97}$.

Las congregaciones masivas para atacar, protestar o requerir un privilegio se desarrollaban en momentos extraordinarios. De algún modo imitando los desfiles de la intimidación de los oligarcas y sus clientelas (reproduciendo un ritual aprendido en las procesiones religiosas, pero con diferente fin), el común sabía organizarse a la hora de reclamar sus derechos. Como en las manifestaciones contemporáneas, en el pasado existía una coreografía de las masas instituida por la tradición, patrimonio del pueblo, en la que estaban concretados los espacios de protesta, los gritos, los gestos de reivindicación y los actos que se debían desarrollar. En 1468, por ejemplo, una vez que Enrique IV entró en Toledo clandestinamente, con el fin de asegurar su control, un domingo por la tarde cierta gente de la cibdad, unas dos mil personas -escribe el cronista Enríquez del Castillo-, con más liviandad de poco seso que con conoş̧imiento de rrazón, después que uvieron comido, hallándose más llenos de vino que de prudençia, por ynduçimiento de otros tales como ellos, se congregaron ante el palacio de Pedro López de Ayala, donde el rey permanecía, para exigirle la confirmación de sus privilegios y una nueva franqueza en el pago de alcabalas; a lo que el rey accedió, ante el asombro de los oligarcas, que no entendían por qué el rey autorizaba la protesta accediendo a las solicitudes, en descrédito de las instituciones gubernativas. Con su actitud Enrique estaba legitimando la acción de la comunidad, lo que podía ser peligroso ${ }^{98}$. No en vano, al día siguiente, lunes, volvió a reunirse una turbamulta para corregir lo pactado, pues al parecer era incorrecto. La alcabala que se había eximido era la de vino y el mosto, lo que beneficiaba a los herederos de las viñas, y no a la globalidad de la población, de manera que se pretendía que el rey extendiese el carácter exento de alcabala a todos los productos. Esta vez, sin embargo, la respuesta de los oligarcas fue feroz, y la manifestación fue disuelta sin piedad. El conde de Fuensalida y sus esbirros entraron a caballo en medio de la multitud atropellando a los alborotadores; y luego a unos les cortaron las orejas, a otros los azotaron, y unos cuantos terminarían en la horca.

\section{A MODO DE CONCLUSIÓN}

Una de las cuestiones en torno a las protestas urbanas sobre la que aún queda mucho por escribir es la referente a cómo influyó la cultura erudita en la cultura popular, y viceversa, en relación a los principios ideológicos que justificaban los alzamientos. Algunos autores han advertido que, en las últimas décadas del siglo xv, y gracias a la influencia del humanismo, en tierras castellanas comenzaron a calar mensajes del aristotelismo político

97 Carrillo de Huete, Pero. Crónica del halconero de Juan II, ed. de Juan de Mata Carriazo. Madrid: Espasa-Calpe, 1946, p. 511.

98 López Gómez, Los Reyes Católicos y la pacificación de Toledo, pp. 77-78. 
ÓSCAR LÓPEZ GÓMEZ

EN LA TOLEDO BAJOMEDIEVAL

que ponían el énfasis en la responsabilidad de los ciudadanos en la paz, la justicia y el bien común 99 . Figuras clave de esa corriente intelectual serían Pedro Martínez de Osma, Fernando de Roa, Rodrigo Sánchez de Arévalo, Diego de Valera, Alonso de Cartagena, Fernando del Pulgar, Diego de Deza, Alonso de Santa Cruz, Juan Barba y, especialmente, Alfonso de Madrigal, el Tostado, que llegaría a proponer ideas revolucionarias para su época ${ }^{100}$, hasta el punto de ser tenido por un precursor de la democracia. El éxito del aristotelismo en los medios universitarios y la confluencia del humanismo y el conciliarismo forjaron una corriente de pensamiento que, sin ser crítica con el sistema político y social vigente, apostaba por su enmienda, y el consenso, el diálogo y una mayor igual ${ }^{101}$. Si dicha corriente se vio influida por el modo de pensar de las masas sociales, o hasta qué punto los eruditos lograron influir en la cosmovisión del pueblo, es algo sobre lo que queda por investigar.

En el caso de Toledo las ideas cultas que circulaban en los círculos de erudición y las universidades sí se dejaron notar en las argumentaciones y planteamientos del grupo política, social y económicamente más dinámico, al que pertenecían linajes como el de los Cota, Franco, Oseguera, Madrid, Alcalá, Gómara, Navarra o Bargas, que eran parte sustancial de la élite del común (a pesar de sus orígenes judíos) y conformaban una minoría intelectual laica. El carácter reivindicativo de su discurso perseguía esencialmente permitir a las familias de la élite pechera ascender en la política y en la sociedad, para lo que era básica la manipulación de conceptos tales como sosiego, república, paz, justicia o bien común. Se trataba de un discurso en el que lo que estaba en juego era el poder, de modo que no se criticaba tanto la organización gubernativa de la urbe como su carácter cerrado y excluyente; como el hecho de que no se dejase a determinadas personas entrar en el gobierno solo por su estirpe.

Por el contrario, el discurso de quienes habitaban en parroquias pobres era provocador. Dichas parroquias - las de San Lorenzo, San Marcos y Santiago; los arrabalespadecieron en la segunda mitad del siglo XV una enorme presión demográfica, debido a la llegada de inmigrantes en busca de condiciones de subsistencia dignas. Aun compartiendo un deseo de mayor igualdad, el discurso de quienes vivían en estos barrios era diferente del discurso reformador -más teórico y menos pasional- de quienes hablaban desde el humanismo cívico, en una situación política y económica confortable. No resulta baladí que desde el siglo xiv las revueltas se radicalizaran al entrometerse en ellas las gentes del arrabal ${ }^{102}$.

99 Asenjo González, María. «El pueblo urbano: el común». Medievalismo, 2004, vol. 13-14, pp. 181-194. En concreto p. 191.

100 Bonachía Hernando, Juan Antonio. «Ciudad ideal y óptimo gobierno en la Castilla del cuatrocientos: la influencia del modelo clásico griego en Alonso de Madrigal». Res publica, 2008, vol. 20, pp. 23-41. En concreto p. 37.

101 Nieto Soria, José Manuel. «El conflicto como representación: expresiones de la cultura política trastámara». En Nieto Soria (dir.), El conflicto en escenas, pp. 15-55. En concreto pp. 31-32.

102 López Gómez, Óscar. «La población marginada de Toledo a finales del siglo XV». En VAL VALDIvieso, María Isabel del y Martínez Sopena, Pascual (dirs.). Castilla y el mundo feudal. Homenaje al profesor Julio Valdeón. Valladolid: Junta de Castilla y León-Universidad de Valladolid, 2009, tomo III, pp. 369-382. En concreto pp. 373 y ss. 
ÓSCAR LÓPEZ GÓMEZ

Más allá de las pugnas de facciones, las protestas tuvieron un efecto positivo; pero no las que se concebían en los bajos estratos sociales, sino aquellas a cuya vanguardia se puso la élite del común que ansiaba ascender políticamente. En Valladolid, por ejemplo, en 1351 junto a las voces de Reoyo y Tovar se instauró la voz del pueblo: un tercer bando discordante, constituido por artesanos y prósperos mercaderes cuyo acceso a la caballería estaba vetado. Su capacidad de acción, empero, pronto se vio deslucida, pues «en su afán de movilizar un capital social que los apoyase» la institución empezó a abrirse a gente menuda que la radicalizó, lo que hizo que el rey Alfonso XI la prohibiera ${ }^{103}$. Décadas después, en 1422, pasó algo similar en Toledo con el Cabildo de jurados, instituido de igual modo, y en gran parte, por las protestas de la élite pechera ${ }^{104}$, que supo manipular conceptos como bien común, justicia y paz para conseguir sus fines de ascenso político, al tiempo que las protestas de los menores se quedaban en nada ${ }^{105}$.

Las ideas de las clases bajas fracasaron, entre otros motivos, por el descrédito de que las imbuyeron algunos de los intelectuales de la corona, que las calificarían de aspiraciones sin sentido de gente bellaca. Intelectuales que, al contrario, no dudaron en alabar las labores pacificadoras de la realeza, que en Toledo se sustentaron justamente sobre la segunda oligarquía -compuesta por los caballeros de clase baja y la élite del común-, a costa de recortar poder a los caballeros poderosos y, en especial, a los menores.

\section{4}

\section{REFERENCIAS BIBLIOGRÁFICAS}

Alan Sizer, Michael. Making Revolution Medieval: Revolt and Political Culture in Late Medieval Paris. Minessota: University of Minessota, 2008.

Aranda Pérez, Francisco José. «Poder municipal, oligarquías urbanas y cabildo de jurados en Toledo entre los siglos XV y xvi». En Hinojosa Montalvo, José y Pradells Nadal, Jesús (eds.). 1490 en el umbral de la Modernidad. El Mediterráneo y las ciudades en el tránsito entre los siglos XV y XVI. Valencia: Generalitat Valenciana, 1994, vol. II, pp. 109-120.

Aranda Pérez, Francisco José. «Privilegio de Juan II por el que se crea, junto al Regimiento, el Cabildo de jurados de Toledo, a imitación del de Sevilla». Beresit, 1992, vol. 4, pp. 51-55.

Aranda Pérez, Francisco José. Poder municipal y Cabildo de Jurados en la Edad Moderna (siglos XV-XVIII). Toledo: Ayuntamiento de Toledo, 1992.

Arranz Guzmán, Ana. "Excomunión eclesiástica y protesta ciudadana». En Nieto Soria, José Manuel (dir.). El conflicto en escenas. La pugna política como representación en la Castilla bajomedieval. Madrid: Sílex, 2010, pp. 211-246.

Asenjo González, María. «El pueblo urbano: el común». Medievalismo, 2004, vol. 13-14, pp. 181-194.

103 Martín Romera, «Bandos, violencia y altercación de la paz», p. 177.

104 Aranda Pérez, Francisco José. «Poder municipal, oligarquías urbanas y cabildo de jurados en Toledo entre los siglos xv y xvi». En Hinojosa Montalvo, José y Pradells Nadal, Jesús (eds.). 1490 en el umbral de la Modernidad. El Mediterráneo y las ciudades en el tránsito entre los siglos XV y XVI. Valencia: Generalitat Valenciana, 1994, vol. II, pp. 109-120.

105 JaRA Fuente, José Antonio. «Con mucha afecçión e buena voluntad por servir a bien público: la noción "bien común" en perspectiva urbana. Cuenca en el siglo xv». Studia Historica. Historia Medieval, 2010, vol. 28, pp. 55-82. 
ÓSCAR LÓPEZ GÓMEZ

Barros, Carlos. Mentalidad justiciera de los irmandiños, siglo XV. Madrid: Siglo XXI, 1990.

BAzÁN DíAz, Ińaki. «Sy fuere villano que lo enforquen por ello, e sy fuere fijodalgo que le enposen fasta que muera. La pena de muerte en la legislación vasca medieval». En GonzÁlez Mínguez, César y BAzÁn DíAz, Ińaki (dirs.). El discurso legal ante la muerte durante la Edad Media en el nordeste peninsular. Guipúzcoa: Universidad del País Vasco, 2006, pp. 291-423.

Belloré, Maïté y Soria, Myriam (dirs.). La rumeur au Moyen Âge. Du mépris à la manipulation ( $V^{e}-X V^{e}$ siècle). Rennes: Presses Universitaries de Rennes, 2011.

Benito Ruano, Eloy. «El memorial contra los conversos del bachiller Marcos García de Mora». Sefarad. Revista de Estudios Hebraicos y Sefardies, 1957, vol. 17/2, pp. 314-351.

Benito Ruano, Eloy. La prelación ciudadana. Las disputas entre las ciudades de la Corona de Castilla. Toledo: Centro Universitario de Toledo, 1972.

Benito Ruano, Eloy. Toledo en el siglo XV. Vida política. Madrid: Consejo Superior de Investigaciones Científicas, 1961.

Blackledge, Paul. Reflections on the Marxist Theory of History. Manchester: University Press, 2006.

Bodden, M. C. Language as the Site of Revolt in Medieval and Early Modern England: Speaking as a Woman. London: Palgrave Macmillan, 2011.

Bonachía Hernando, Juan Antonio. «Ciudad ideal y óptimo gobierno en la Castilla del cuatrocientos: la influencia del modelo clásico griego en Alonso de Madrigal». Res publica, 2008, vol. 20, pp. 23-41.

Carrasco Manchado, Ana Isabel. «El rumor político. Apuntes sobre la opinión pública en la Castilla del siglo Xv». Cuadernos de Historia de España, 2006, vol. 80, pp. 65-90.

Carrillo de Huete, Pero. Crónica del halconero de Juan II, ed. de Juan de Mata Carriazo. Madrid: Espasa-Calpe, 1946.

Challet, Vincent. "Moyran, los traidors, moyran. Cris de haine et sentiment d'abandono dans les villes languedociennes à la fin du XIV ${ }^{e}$ siècle». En LeCuppre-Desjardin, Elodie y Van Bruaene, Anne-Laure (eds.). Emotions in the Heart of the City (14 th $-16^{\text {th }}$ Century): studies in European Urban History (1100-1800). Turnhout: Brepols, 2005, pp. 83-92.

Challet, Vincent. «Nemine discrepante? Discordias y comunicación política en el seno del consulado montpellerino a fines de la Edad Media». Edad Media. Revista de Historia, 2012, vol. 13, pp. 143-161.

Сонn, Samuel K. (Jr.). Lust for Liberty. The politics of Social Revolt in Medieval Europe, 12001423. Italy, France and Flanders. Cambridge, Massachusetts and London: Harvard University Press, 2008.

Costantini, Valentina. "On the red line across Europe: Butchers and Rebellions in fourteenth-century Siena». Social History, 2016, vol. 41/1, pp. 72-92.

Costantini, Valentina. «Siena, 1318: la cogiura di "carnaioli", notai e magnati contro il governo dei Nove». Studi Storici, 2011, vol. 52/1, pp. 229-252.

Costantini, Valentina. «Tra lavoro e rivolta: i carnaioli senesi nello specchio del Costituto del 1309-10». En Giordano, Nora y Piccinni, Gabriella (a cura di). Siena nello specchio del suo Costituto in volgare del 1309-1310. Siena: Pacini Editore, 2014, pp. 219-247.

Dacosta, Arsenio. "Violencia banderiza y escritura histórica: un estudio comparado». En Fernández de Larrea, Jon Andoni y Díaz de Durana, José Ramón (eds.). Memoria e historia. Utilización política en la Corona de Castilla al final de la Edad Media. Madrid: Sílex, 2010, pp. 101-140.

Dumolyn, Jan y Haemers, Jelle. «A Bad Chicken Was Brooding: Subversive Speech in Late Medieval Flanders». Past and Present, 2012, vol. 214, pp. 45-86.

Dumolyn, Jan. «Cries and Shouters. The Discourse on Radical Urban Rebels in Late Medieval Flanders». Journal of Social History, 2008, vol. 42/1, pp. 111-135. 
ÓSCAR LÓPEZ GÓMEZ

LA CIBDAD ESTÁ ESCANDALIZADA. PROTESTAS SOCIALES Y LUCHA DE FACCIONES

EN LA TOLEDO BAJOMEDIEVAL

Dumolyn, Jan. «Political Communication and Political Power in the Middle Ages: a Conceptual Journey». Edad Media. Revista de Historia, 2012, 13, pp. 33-55.

El proceso contra Juan Gaitán. Toledo: Carmen Vaquero, 2002.

FourQuin, Guy. Los levantamientos populares en la Edad Media. Madrid: DAF, 1979.

Gauvard, Claude. «Rumeur et stereotypes à la fin du Moyen Âge». En La circulation des nouvelles au Moyen Âge. XXIV Congrés de la SHMES (Avignon, juin 1993). Paris: La Sorbonne-École Française de Rome-Palais Farnèse, 1994, pp. 157-177.

González Soriano, José Antonio. Racionalidad revolucionaria: apunte de epistemología para el materialismo histórico. Madrid: Biblioteca Nueva, 2008.

Haemers, Jelle. «A Moody Community? Emotions and Ritual in Late Medieval Urban Revolts». En Lecuppre-Desjardin, Elodie y Van Bruaene, Anne-Laure (eds.). Emotions in the Heart of the City (14 $4^{\text {th }}-16^{\text {th }}$ Century): studies in European Urban History (1100-1800). Turnhout: Brepols, 2005, pp. 73-74 y 81.

Haemers, Jelle. «Social Memory and Rebellion in Fifteenth-Century Ghent». Social History, 2011, vol. XXXVI, pp. 443-463.

Izquierdo Benito, Ricardo. «La noche de Toledo en el siglo xv». Boletín de la Real Academia de Ciencias Históricas de Toledo, 1994, vol. 30, pp. 123-142.

Jara Fuente, José Antonio. "Con mucha afecçión e buena voluntad por servir a bien público: la noción "bien común" en perspectiva urbana. Cuenca en el siglo XV". Studia Historica. Historia Medieval, 2010, vol. 28, pp. 55-82.

Jara Fuente, José Antonio. «Legitimando la dominación en la Cuenca del siglo Xv: la transformación de los intereses particulares a través de la definición del bien común». Anales de la Universidad de Alicante, 2009-2012, vol. 16, pp. 93-119.

KaYe, Harvey J. La educación del deseo: los marxistas y la escritura de la Historia. Madrid: Talasa, 2007.

Ladero Quesada, Miguel Ángel. «Proyecto político y grupos sociales en la España de los Reyes Católicos». En Lecturas sobre la España histórica. Madrid: Real Academia de la Historia, 1998, pp. 71-112.

LeCuppre-Desjardin, Elodie. «Proclamar la autoridad, afirmar el poder, reducir al pueblo: una reflexión sobre la comunicación política en los antiguos Países Bajos borgoñones». Edad Media. Revista de Historia, 2012, vol. 13, pp. 103-121.

Lop Otín, María José y López Gómez, Óscar. «Entre la paz y el caos. Acción subversiva y actividad pacificadora en las élites urbanas del siglo xv: Toledo, 1441-1495». Hispania [en prensa].

López Gómez, Óscar. «Abusos de poder y desacato a la justicia en el ámbito urbano medieval: Toledo (1085-1422)». Historia. Instituciones. Documentos, 2005, vol. 32, pp. 211-245.

López Gómez, Óscar. «Después de Isabel la Católica: la reaparición de la lucha de facciones en Toledo». Anales de la Universidad de Alicante, 2012, vol. 18, pp. 315-343.

López Gómez, Óscar. «El impacto de las revueltas urbanas en el siglo xv. A propósito de la rebelión de 1449 en Toledo». Edad Media. Revista de Historia, 2014, vol. 15, pp. 173-190.

López Gómez, Óscar. «Fiesta y ceremonia del poder regio en Toledo a fines de la Edad Media». En Martínez-Burgos García, Palma y Rodríguez González, Alfredo (coords.). La fiesta en el mundo hispánico. Cuenca: Universidad de Castilla-La Mancha, 2004, pp. 245-279.

López Gómez, Óscar. "La población marginada de Toledo a finales del siglo XV». En VAL VALDivieso, María Isabel del y Martínez Sopena, Pascual (dirs.). Castilla y el mundo feudal. Homenaje al profesor Julio Valdeón. Valladolid: Junta de Castilla y León-Universidad de Valladolid, 2009, tomo III, pp. 369-382.

López Gómez, Óscar. «Pas e sosyego. Un argumento de acción política en la Castilla bajomedieval». Medievalismo, 2006, vol. 16, pp. 41-71. 
ÓSCAR LÓPEZ GÓMEZ

López GómEz, Óscar. «Representatividad política y rebelión social a finales del Medievo: las asambleas del común en Toledo (1478-1522)». Anuario de Estudios Medievales, 2012, vol. 42/2, pp. 727-753.

López Gómez, Óscar. Álvaro de Luna y Escalona. Poder, propaganda y memoria histórica en el otońo de la Edad Media. Toledo: Diputación Provincial, 2013.

López Gómez, Óscar. Los Reyes Católicos y la pacificación de Toledo. Madrid: Castellum, 2008.

López Gómez, Óscar. Violencia urbana y paz regia: el fin de la época medieval en Toledo (14651522). Tesis doctoral leída en la Facultad de Humanidades de Toledo, 2006. En RUIdeRA [Repositorio Universitario Institucional de Recursos Abiertos. Universidad de Castilla-La Mancha]: http://hdl.handle.net/10578/2771.

López Gómez, Óscar y Ávila Seoane, Nicolás. Escalona, 1083-1554. De la repoblación a los tiempos del Lazarillo. Toledo: Diputación Provincial, 2011.

MaCKaY, Angus. "La conflictividad social urbana». En Las ciudades andaluzas (siglos XII-XVI). Actas del VI Coloquio Internacional de Historia Medieval Andaluza. Málaga: Universidad, 1991, pp. 509-524.

Madero, Marta. Manos violentas, palabras vedadas: la injuria en Castilla y León (siglos XII-XV). Madrid: Taurus, 1992.

Martín Cea, Juan Carlos y Bonachía Hernando, Juan Antonio. "Oligarquías y poderes concejiles en la Castilla bajomedieval: balance y perspectivas». En Narbona Vizcaíno, Rafael (comp.). Oligarquias politicas y élites económicas en las ciudades bajomedievales (siglos XIII-XVI), Revista d'Historia Medieval, 1998, vol. 9, pp. 17-40.

Martín Gamero, Antonio. Historia de la ciudad de Toledo, sus claros varones, sus monumentos. 2 vols. Toledo: Imprenta de Severiano López Fando, 1862.

Martín Romera, María Ángeles. «Bandos, violencia y altercación de la paz pública en las ciudades bajomedievales: el caso de Valladolid». En Arranz Guzmán, Ana; Rábade Obradó, María del Pilar y Villarroel González, Óscar (coords.). Guerra y paz en la Edad Media. Madrid: Sílex, 2013, pp. 163-187.

Martínez Gil, Fernando. "Furia popular. La participación de las multitudes urbanas en las comunidades de Castilla». En Martínez GiL, Fernando (coord.). En torno a las comunidades de Castilla. Actas del Congreso Internacional "Poder, conflicto y revuelta en la España de Carlos I». Cuenca: Universidad de Castilla-La Mancha, 2002, pp. 309-364.

Martínez Gil, Fernando. La ciudad inquieta. Toledo comunera, 1520-1522. Toledo: Instituto Provincial de Investigaciones y Estudios Toledanos-Diputación Provincial de Toledo, 1993.

Martínez Gil, Fernando. La invención de Toledo: imágenes históricas de una identidad urbana. Ciudad Real: Almud, 2007.

Menache, Sophia. The Vox Dei. Communication in the Middle Ages. Oxford: University Press, 1990.

Mollat, Michel y Wolff, Philippe. Uñas azules, Jacques y ciompi. Las revoluciones populares en Europa en los siglos XIV y XV. Madrid: Siglo XXI, 1989.

Monsalvo Antón, José María. "Ideario sociopolítico y valores estamentales de los pecheros abulenses y salmantinos (ss. XIII-Xv)». Hispania. Revista Española de Historia, 2011, vol. 71, n. ${ }^{\circ}$ 238, pp. 325-362.

Monsalvo Antón, José María. La Baja Edad Media en los siglos XIV-XV. Política y cultura. Madrid: Síntesis, 2000.

Montero Málaga, Alicia Inés. «Vecindades y procuradores, protesta y conflicto en Burgos: ¿̨verdadero discurso del común o expresión del clientelismo nobiliario?». Comunicación dada en la XXVII Asamblea General de la SEEM. Congreso Internacional Formas de protesta, movilización y lucha política... 
ÓSCAR LÓPEZ GÓMEZ

LA CIBDAD ESTÁ ESCANDALIZADA. PROTESTAS SOCIALES Y LUCHA DE FACCIONES

EN LA TOLEDO BAJOMEDIEVAL

Netanyahu, Benzion. Los origenes de la Inquisición en la España del siglo XV. Barcelona: Crítica, 1999.

NiETo Soria, José Manuel. «El conflicto como representación: expresiones de la cultura política trastámara». En Nieto Soria, José Manuel (dir.). El conflicto en escenas. La pugna política como representación en la Castilla bajomedieval. Madrid: Sílex, 2010, pp. 15-55.

Nieto Soria, José Manuel. «El pregón en la vida política de la Castilla trastámara». Edad Media. Revista de Historia, 2012, vol. 13, pp. 77-102.

Oliva Herrer, Hipólito Rafael. "¿Qué es la comunidad? Reflexiones acerca de un concepto político y sus implicaciones en Castilla a fines de la Edad Media». Medievalismo, 2014, vol. 24, pp. 281-306.

Ormrod, W. Mark. «Murmur, Clamour and Noise: Voicing Complaint and Remedy in Petition to the English Crown, c. 1300-c. 1460». En Ormrod, W. Mark y Musson, Anthony (eds.). Medieval Petition: Grace and Grievance. Woodbridge: York Medieval Press in association with Boydell \& Brewer, 2009, pp. 135-155.

Palencia, Alfonso de. Gesta Hispaniensia ex annalibus sucrum dierum collecta, ed. de B. Tate y J. Lawrence. Madrid: Real Academia de la Historia, 1998.

Petrucci, Armando. «Potere, spazi urbani, scriture esposte: proposte ed esempi». En Culture et idéologie dans la genèse de l'État Moderne. Actes de la table ronde organisée par le Centre National de la Recherche Scientifique et l'École française de Rome, Rome, 15-17 octubre 1984. Paris: École Française de Rome-Palais Farnèse, 1985, pp. 57-84.

Pulgar, Fernando del. Crónica de los Señores Reyes Católicos don Fernando y doña Isabel de Castilla y Aragón. En Crónicas de los Reyes de Castilla. Madrid: BAE, 1953, vols. LXVIII y LXX.

Rodríguez-Picavea Matilla, Enrique. La villa y la Tierra de Talavera en la Plena Edad Media: orígenes, consolidación y crecimiento de un concejo de realengo (siglos XI-XIII). Talavera de la Reina: Ayuntamiento de Talavera de la Reina, 1996.

Rudé, Georges. Revuelta popular y conciencia de clase. Barcelona: Crítica, 1981.

Ruiz Taboada, Arturo y López Gómez, Óscar. «Arqueología e historia de una casa bajomedieval en Toledo". Melànges de la Casa de Velázquez, 2006, vol. 36/1, pp. 195-213.

SATO, Hitomi. «Fazioni e microfazioni: guelfi e ghibellini nella montagna bergamasca del Trecento». Bergomum. Bollettino Annuale della Civica Biblioteca Angelo Mai di Bergamo, 20092010, vol. 104-105, pp. 149-170.

Sсотт, James C. Domination and the Arts of Resistance: Hidden Transcripts. Michigan: Yale University, 1990.

SuÁrez Álvarez, María Jesús. El concejo de Talavera de la Reina durante la Baja Edad Media (13691504). Oviedo: Universidad de Oviedo, 1978.

SuÁrez Álvarez, María Jesús. La villa de Talavera y su tierra en la Edad Media (1369-1504). Oviedo: Universidad de Oviedo, 1982.

TÉllez Aguilera, Abel. La delincuencia de las muchedumbres. (Estudio criminológico y jurídicopenal de la muchedumbre criminal). Madrid: Universidad de Alcalá de Henares, 1991.

VAl Valdivieso, María Isabel del. "Conflictividad social en la Castilla del siglo Xv». Acta Histórica et Archaelogica Medievalia, 2005, vol. 26, pp. 1033-1050.

VÁzquez Gestal, Pablo. «Despegándose del texto. Los juegos de la "Nueva Historia Cultural": Descripción, narración e interpretación». Memoria y Civilización, 2001, vol. 4, pp. 151-186.

Verdon, Jean. Information et désinformation au Moyen Âge. Paris: Persin, 2010.

Walker, Simon. «Rumour, Sedition and Popular Protest in the Reign of Henry IV». Past and Present, 2000, vol. 166, pp. 31-65.

Wiскнам, Chris. «Gossip and Resistance among the Medieval Peasantry». Past and Present, 1998, vol. 160, pp. 3-24. 
